\title{
GSSE
}

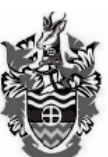

\section{Early Permian diamond-bearing proximal eskers in the Lichtenburg/Ventersdorp area of the North West Province, South Africa}

\author{
Mike C.J. de Wit \\ University of Pretoria/Tsodilo Resources Ltd, P O Box 466, Kleinmond, 7195, South Africa \\ e-mail: dewit@icon.co.za
}

() 2016 December Geological Society of South Africa

\begin{abstract}
Diamond-bearing gravels of the Lichtenburg-Ventersdorp area of the North West Province are associated with north-south orientated sinuous 'runs' that occur almost entirely on a flat erosional surface of the Malmani dolomites (Transvaal Supergroup) at some 1,500 m elevation. East to west, this dolomite plain measures $150 \mathrm{~km}$, and northsouth it is on average $40 \mathrm{~km}$ wide. This unconformity, which first developed before the Pretoria Group sedimentation over a period of at least $80 \mathrm{Myr}$, is marked by siliceous breccias (palaeo-karst infill) and conglomerates (reworked breccias). It was exhumed in pre-Karoo and post-Gondwana times. Glacial pavements and remnants of thin Lower Karoo sediments are also found on this polyphase surface. The gravels that make up these 'runs' and sinkholes directly or indirectly linked to these runs, are coarse-grained, very poorly-sorted, and are best described as diamictites. The 'runs' are narrow, elongated, generally positive ridges that meander across the dolomite surface and are up to $30 \mathrm{~km}$ long and between 80 to $300 \mathrm{~m}$ wide. They have always been regarded as postCretaceous drainage features linked to southward-flowing river systems. Diamonds were discovered in these 'runs' and they have produced some 12 million carats. However, no Cainozoic fossils or artefacts have ever been found in almost 90 years of mining. From new field evidence, geomorphological studies, age dating from inclusions in diamond and zircon and clay analyses, it is proposed that these coarse-grained runs represent proximal palaeoeskers of the last deglaciation of the Dwyka continental ice sheet, that are preserved on this ancient 'palimpsest' surface. The age of the deposit is constrained by two populations of agate within the diamictites that are linked to two separate volcanic units of the Pretoria Group. In addition, the youngest crustal zircon ages from the gravels are $1 \mathrm{Ba}$, but mantle zircons from Lichtenburg suggest that these have been derived from Cambrian age kimberlites. Analysis of inclusions in diamond support a Neoproterozoic to Cambrian source for the diamonds, so the absence of diamonds from Mesozoic kimberlites and Cainozoic fossils within the gravels support the conclusion that the runs are of Karoo age.
\end{abstract}

\section{Introduction}

Diamond-bearing gravels of the Lichtenburg - Ventersdorp area occur mainly as sinuous ridges or 'runs' and in isolated sinkholes that occur almost entirely on a flat to very gently southward sloping surface developed on chert-rich and chert-poor formations the Malmani Subgroup dolomites of the Transvaal Supergroup (Figure 1). The dolomite surface is overlain by basal Rooihoogte Formation breccias, followed by quartzites and conglomerates of the Timeball Hill and Boshoek Formations, and Hekpoort Formation volcanics, all part of the Pretoria Group. These are preserved to the north of the dolomites as east-west orientated ridges decreasing in elevation into the Bushveld Basin.

To the south of the Lichtenburg - Ventersdorp area, the Malmani dolomites overlie the Black Reef Formation, at the base of the Transvaal Supergroup, and further south are Ventersdorp and Witwatersrand Supergroups rocks, respectively. 
EARLY PERMIAN DIAMOND-BEARING PROXIMAL ESKERS IN THE LICHTENBURG/VENTERSDORP AREA OF THE NORTH WEST PROVINCE, SOUTH AFRICA

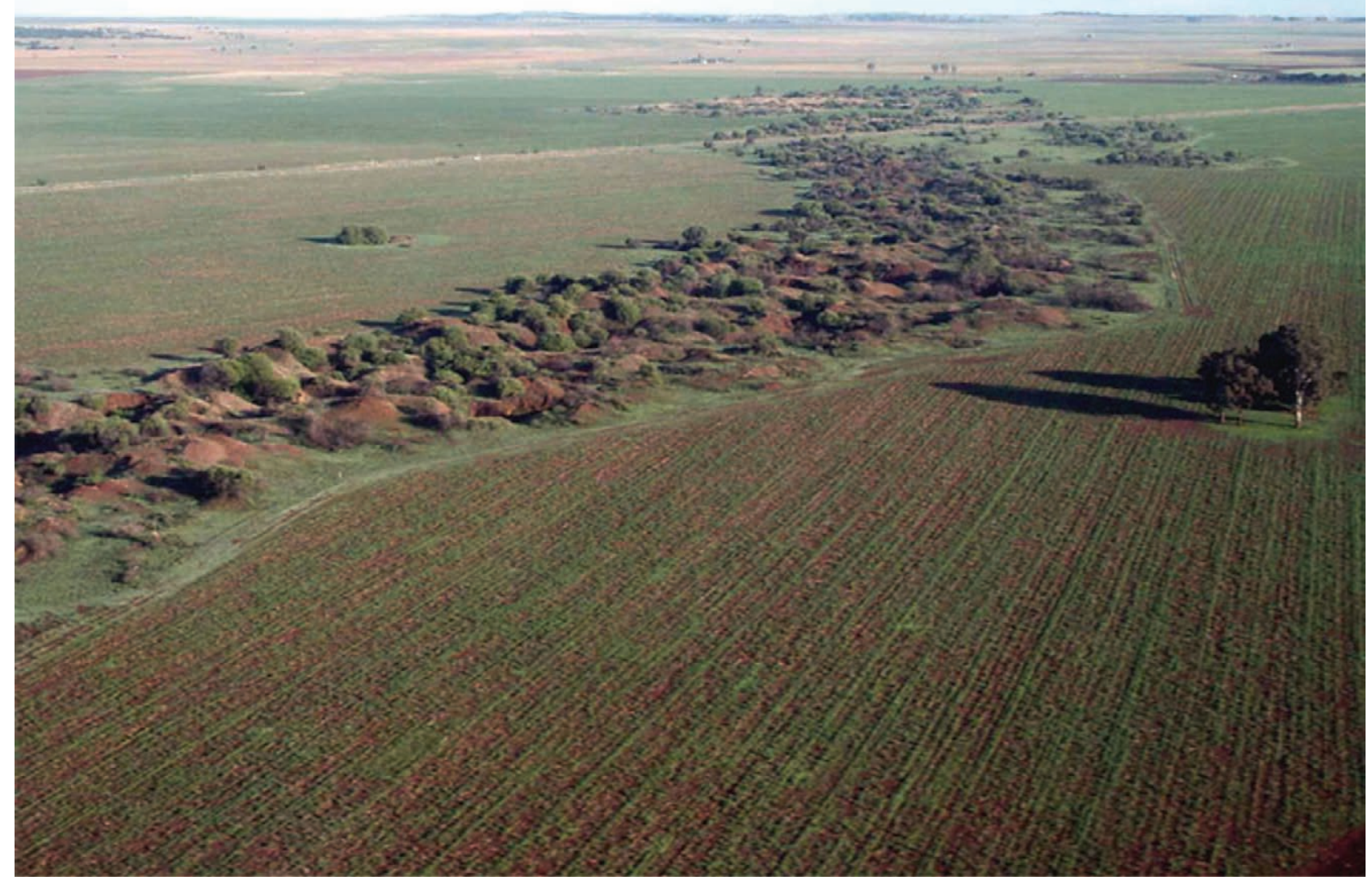

Figure 1. View looking north at the end of the Zwartplaas gravel 'run' meandering across the dolomite erosion surface.

The term 'runs' was first used by Du Toit (1935) to describe the narrow, elongated, generally positives ridges that meander across the dolomite surface at an elevation of some 1,500 $\mathrm{m}$ amsl. The runs are mainly composed of gravels and breccias, coarse sands and minor clay units. They are referred to as 'older gravels' (Du Toit, 1951) and are preserved almost entirely on the dolomite surface. They occur from close to Randfontein in the east to midway between Lichtenburg and Mahikeng, over an area of approximately $150 \mathrm{~km}$ (east-west) by $40 \mathrm{~km}$ (northsouth). In the west, around Lichtenburg, the runs are orientated northeast-southwest; in the central part, near Ventersdorp, they are almost north-south; and close to Randfontein west-northwest east-southeast (Figure 2). Reworked or younger gravels occur to the south along the Mooi River as terraces, and as a palaeochannel to the southwest near Mahikeng. In this paper, a new depositional model is presented for the diamond-bearing older gravels or 'runs' of the Northern and Eastern fields.

\section{Diamond history}

The first diamonds in the North West Province were reported in 1904 from the area around Bloemhof and Leewdoringstad, derived mainly from Vaal River gravels. In 1906 diamonds were found around Schweizer-Reneke and in 1907 in the
Wolmaransstad area, a region referred to as the Southern Field (Marshall, 1990). Other discoveries were made along the Vaal River around Klerksdorp (1912) and Parys (1922), and in the Harts River (1917). The main discovery north of Lichtenburg (Northern Field), was in 1926 and around Ventersdorp (Eastern Field) after 1914 (Figure 2). The total production from these three fields up to 1984 was 14.4 Mct, equivalent to the production of the Kimberley Mine (Big Hole) during its 44 year life (Marshall, 1987). During that period most of the diamonds came from the Northern Field (9.7 Mct), with the Eastern and Southern Fields each adding some 2.7 Mct and 2.0 Mct, respectively. The average Rand per carat values of those diamonds, based on prices achieved between 1904 and 1984, was 5.3, 8.5 and 34.0 for the Northern, Eastern and Southern Fields, respectively (Marshall, 1987). Although mining has been ongoing on a small scale since 1984, there are no accurate records to add to the database except for organised mining operations near Mahikeng, which realised some 37,344 ct between 1986 and 1992 (Jos Haumann, pers. comm., 2015), the Tirisano mine near Ventersdorp, which produced at least 47,000 ct between 2000 and 2011 (Marshall and Norton, 2012), and the Southern fields, where well over 75,000 ct were added between 2010 and 2013 (Namakwa Diamonds Ltd. annual reports). It is therefore estimated that these alluvial diamond fields combined would have produced well in excess of $15 \mathrm{Mct}$. 


\section{Previous work}

Draper (1927) suggested that the diamonds in these sediments were deposited in a shallow marine environment, in breccia and conglomerate ridges ('runs') before the Pretoria Group sediments were laid down. Harger (1928) strongly disputed this and proposed a post-Karoo, and probably Cainozoic, age for the gravels, deposited by surface streams. This has been the general consensus, with Wellington (1929) modelling a drainage system on the Karoo cover that became superimposed on the dolomites, and which disappeared due to 'underground piracy'. Williams (1930) identified five 'ancient' rivers that flowed to the south, transporting diamonds from an area to the north. Sinclair (1940) referred to 'unstratified' river wash deposited in river channels. Du Toit $(1935,1951)$, who provided the most comprehensive description of these gravels, suggested that the area was traversed by a southward directed river system of Cainozoic and possibly Pleistocene age, a view also supported by Cooks (1968). Du Toit (1951) did make the comment that the gravels in the Northern and Eastern Fields resemble 'morainal deposits'.

Retief (1960) and Davies and Prevost (1978) supplemented Du Toit's detailed descriptions of the various gravel deposits. Mayer (1973) interpreted the Lichtenburg runs as part of a drainage system that developed in response to tectonic movement in the late Cainozoic period. Martini (1976) argued that the southward draining palaeo-river system was captured by the now dominant Limpopo River system at the end of the Cainozoic. Stratten (1979) suggested that the sources for the diamonds was somewhere between southeast Botswana and Swartruggens, and were transported to the south by paleo-rivers. Stettler (1979) and De Wit (1981) concluded that the runs were controlled by leached zones in the dolomites associated with lines of weakness (Stettler et al., 1995). Marshall (1989, 1990) advocated a Cainozoic erosion surface on which the diamonds and gravels occur as a lag deposit. Partridge and Maud (1987), Partridge (1998) and De Wit et al. (2000) modelled southward flowing rivers being active during the Late Cretaceous. Maree $(1987,1988)$ proposed that the gravel deposits were derived from the Dwyka glaciation and that the diamonds originated essentially from old kimberlites. Marshall and Norton (2009) described the gravels as being deposited by subterranean rivers in a karst system in a 'not typical fluvial alluvial' style. Although most suggested that the primary sources for the diamonds were well to the north, De Wit et al. (1998) reported preliminary indications that kimberlites may have intruded the dolomitic karst terrane around Lichtenburg. Finally, Wilson et al.

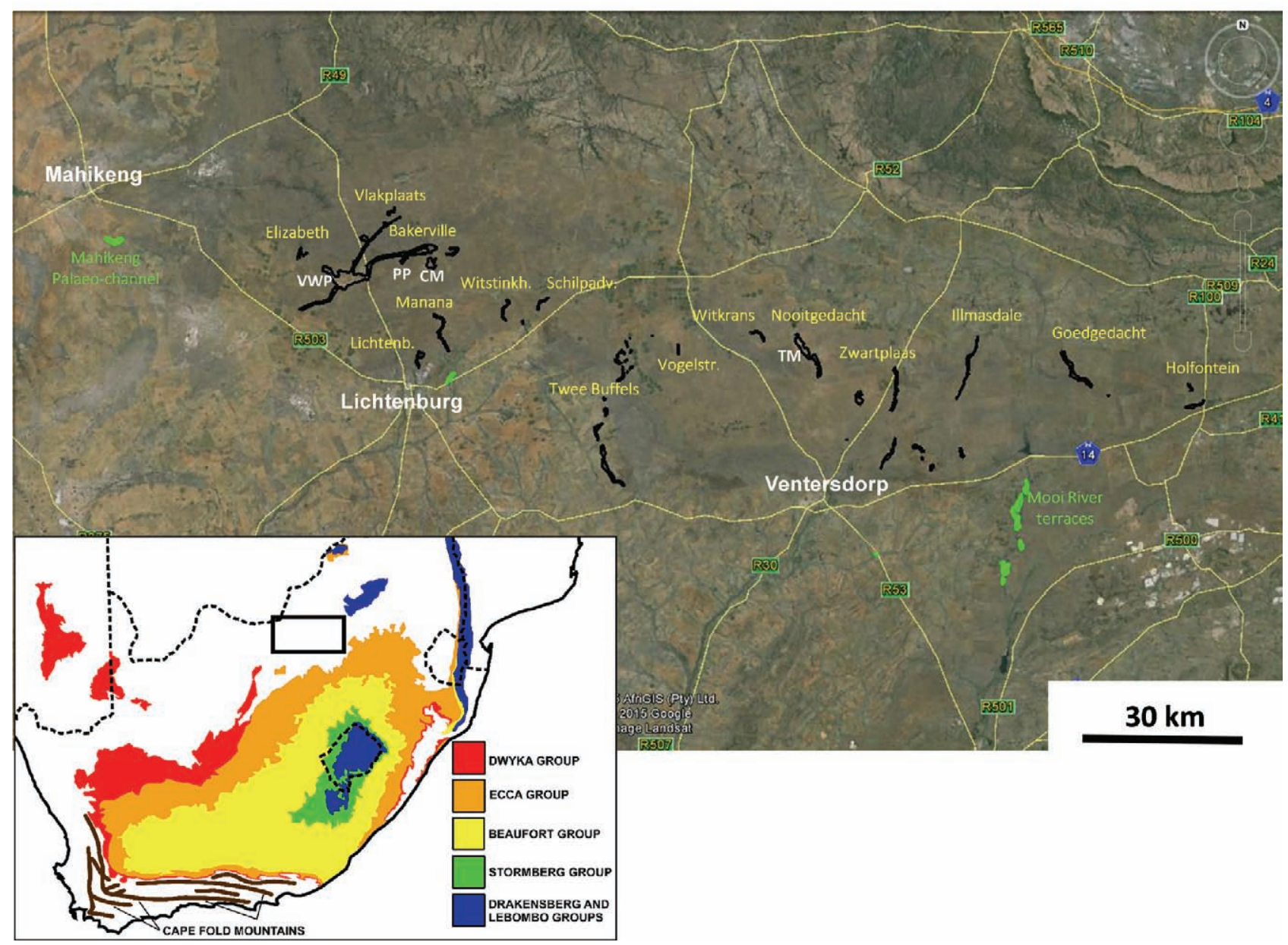

Figure 2. Main gravel 'runs' (black) in the Lichtenburg - Ventersdorp area. Younger reworked deposits in green. Carlisonia Mine (CM), Pienaars pothole (PP), Van Wyks pothole (VWP), Tirisano Mine (TM) (Google image as background). 
EARLY PERMIAN DIAMOND-BEARING PROXIMAL ESKERS IN THE LICHTENBURG/VENTERSDORP AREA OF THE NORTH WEST PROVINCE, SOUTH AFRICA

(2005, 2006 and 2007) have further provided useful summaries and background of these poorly understood deposits.

\section{Geomorphology Geomorphic setting}

The Griqualand-Transvaal axis just to the north of the runs has a maximum elevation just over $1,600 \mathrm{~m}$ and is referred to by Wellington (1929) as the Vaal-Limpopo watershed. It is asymmetrical, having a steep short gradient $(9.3 \mathrm{~m} / \mathrm{km})$ into the Bushveld Basin to the north, and an even and very gentle sloping dolomite surface $(0.8 \mathrm{~m} / \mathrm{km})$, containing the gravel runs, to the south (Figure 3). The Griqualand-Transvaal crustal axis mentioned by Du Toit (1933) coincides with the dolomites and is not so much an axis of uplift but rather a hinge due to the sinking of the Bushveld Basin to the north. The gentle slope of the dolomite surface on the southern side has remained almost untilted according to Du Toit (1933). The Karoo volcanics on the Springbok Flats in the Bushveld Basin to the north has been regarded by some as the source for the agates in the gravels (Williams, 1932; Harger 1928; Du Toit, 1951), and provided, in part, evidence for the subsidence of this basin presently some $350 \mathrm{~m}$ below the level of the gravels (Du Toit, 1951).

Nel et al. (1935) described the development of sinkholes within the dolomites, some of which are filled with Lower Karoo beds, such as on Ryedale 75IQ. Pack et al. (2000) suggested that these have been deposited in shallow lakes in pre-existing karstic depressions in the dolomites; similar features were also described from south of Pretoria within the Chuniespoort dolomites (Wilkins et al., 1987).

At present there are no streams traversing the surface of the dolomite except at its margins. The Mooi River is the only major valley that cuts across the gently sloping dolomite surface. This valley is ' $\mathrm{U}$ ' shaped, almost $100 \mathrm{~m}$ deep and is a northerly extension of the Virginia Valley (Figure 3), a major Carboniferous glacial valley that fed into the main Karoo Basin to the south (Visser and Kingsley, 1982).

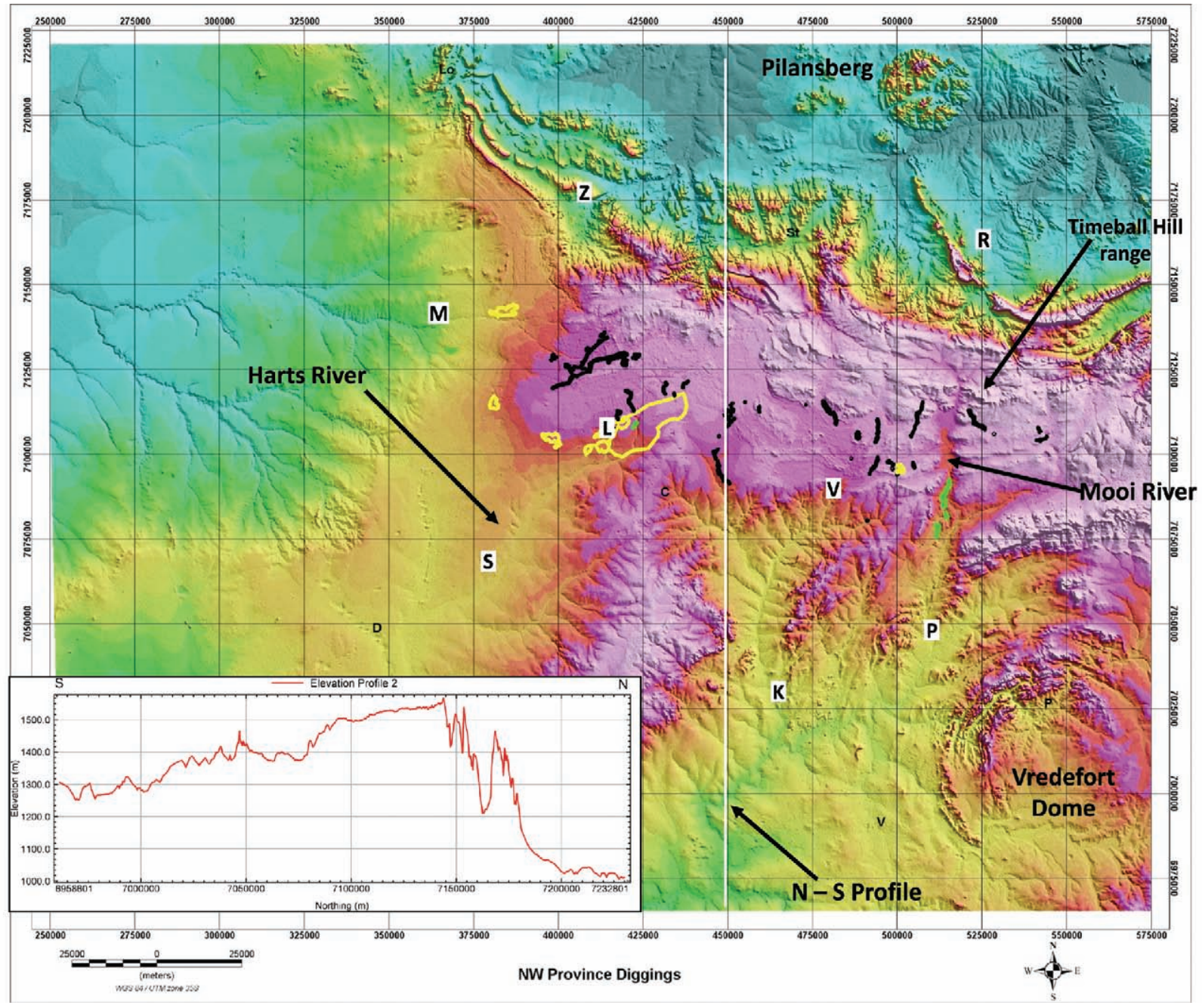

Figure 3. Elevation map based on STRM data: older gravel 'run' (black), reworked younger gravel (green), remnant Karoo (yellow). Insert: north-south profile (at 450K easting; white line on map) across the dolomite plain (between $7090 \mathrm{~K}$ and $7140 \mathrm{~K}$ m northing). Note the Mooi Rivervalley cuts through this dolomite surface. Kleksdorp (K), Lichtenburg (L), Mabikeng (M), Potchefstroom (P), Rustenburg (R), Schweizer-Reneke (S), Ventersdorp (V), Zeerust (Z). Approximate position of Virginia Valley $(v)$. 


\section{Ancient and re-exbumed erosion surface}

As a result of a significant sea level drop at the end of the carbonate phase prior to Timeball Hill sedimentation (Bumby et al., 2012), chert breccias (Figure 4) developed on the weathered carbonates across the various Malmani Subgroup lithologies, forming an irregular karst palaeotopography. Uplift of the Chuniespoort rocks in southern part of the Transvaal Basin enhanced this weathering and chert breccias were reworked to the north into chert conglomerates (Eriksson et al., 2001). These silicified breccias and conglomerates, forming the Rooihoogte Formation, cut across the older underlying lithologies of the Malmani Subgroup to form a major erosional surface (Eriksson et al., 2006). This unconformity, which is overlain by younger Pretoria Group sediments and volcanics, represents a time gap of some 80 Myr (Eriksson et al., 2001). Similar breccias have been described from around Sterkfontein near Randfontein, where it forms a low-angle unconformity with the underlying dolomite (Dirks and Berger, 2013), and north of Lichtenburg where chert breccias of the Rooihoogte Formation, transgress the Frisco, Eccles and the Monte Christo Formations (Department of Water Affairs, North West Dolomite Management Units, 2009).

Waterberg Group sandstones overly the Malmani Subgroup in several places in the Limpopo Province and fill some of the karst topography near Lobatse in Botswana (Martini, 1976). Marshall and Norton (2010) described red sandstone karst infill north of Ventersdorp and similar red sandstone clasts in the basal gravels at the Tirisano mine as belonging to the Waterberg Group and interpreted this as another period of exposure of the Malmani dolomite surface.

Visser (1987a) named an east-west orientated Carboniferous mountainous region over much of northern South Africa, including the Transvaal dolomites, the Cargonian highland. In the north it attained an elevation of between 2,000 and 2,500 m above sea level and to the south the relief was probably at some 1,500 $\mathrm{m}$ above sea level (Visser, 1987a). There was an eastnortheast trending palaeo-escarpment about 1,000 $\mathrm{m}$ high stretching from Prieska to south of Bloemfontein, which

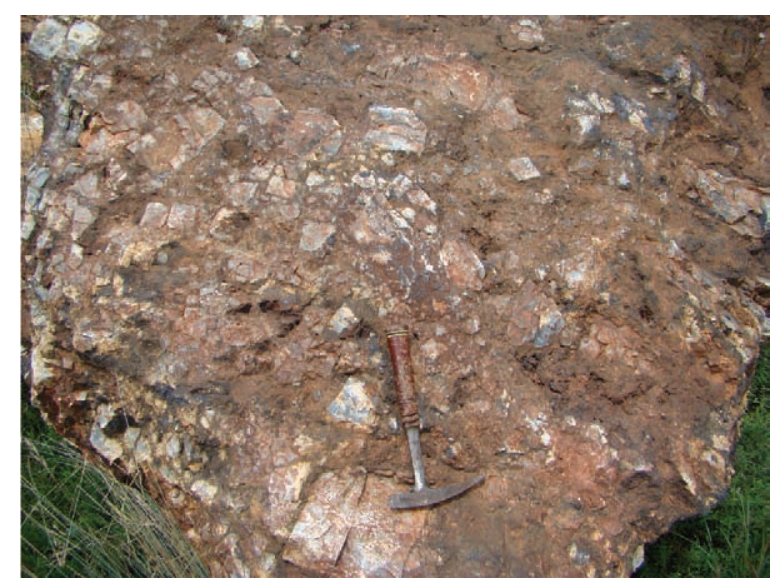

Figure 4. Silicified chert breccia of the Rooiboogte Formation on Doornkop 363JP. Note the angular chert clasts. These breccias generally form positive features in the landscape. separated the main Karoo Basin from the Cargonian Highland (Visser and Kingsley, 1982). Pre-Karoo valleys, such as the Kaap Valley, a southward extension of the Harts Valley and recognised by Du Toit (1910), and the Virginia Valley, first described by Cousins (1950), have cut into this escarpment (Visser and Kingsley, 1982). A northerly extension of this valley can be traced through Potchefstroom along the Mooi River Valley and across the dolomites as far as the Timeball Hill range.

Close to Lichtenburg on Rietdraai 51IP, and within the Harts Valley, there are some well-exposed glacial pavements on Ventersdorp rocks, first described by Von Backström et al. (1953). Scratches and grooves on small roches moutonnées (ca. 3 to $5 \mathrm{~m}$ in length and 0.5 to $1.5 \mathrm{~m}$ high) suggest an ice flow from northeast to southwest. These exhumed glacial pavements show that the pre-Karoo Harts River fed into the main Karoo Basin via the broad shallow Kaap Valley (Visser, 1987b). The Manana, Witstinkhoutboom and Schildpadverdriet runs (Figure 2) all stop short of the edge of this valley and were most likely feeding into it.

Some $10 \mathrm{~km}$ west-southwest of Ventersdorp there are polished surfaces with crescentic markings on quartzites of the West Rand Group. Similar crescentic markings and polish were found on Ventersdorp quartzites and a north-south orientated quartz vein beneath the Twee Buffels and Schilpadverdriet gravel runs, respectively. The polished surfaces are reminiscent of those that have been described as glacial polish over many parts of southern Africa (Ward, 2015). Percussion scars are also common on boulders in most of the runs and require clast-to-clast collision during transport under high energy conditions, which is unlikely to have occurred in meandering rivers on the flat to gentle sloping dolomite surface.

Remnants of Dwyka and Lower Ecca Group sediments are preserved in and around Lichtenburg, and west (Elandsfontein 34IP) and east of the town (Klipbankfontein 26IP) where red Karoo shales have been exposed in the Klein Harts River. To the south, recent drilling on Klipbankfontein 26IP and Rietgat 49IP intersected thicknesses of between 100 and at least $225 \mathrm{~m}$ of Dwyka black shales, varvites, diamictites, sandstones and conglomerates overlying Ventersdorp Supergroup volcanics (Lynn, 2014). Boreholes in the vicinity of the Lichtenburg railway station show that the basal Karoo around Lichtenburg thickens to the southwest from $20 \mathrm{~m}$ to some $60 \mathrm{~m}$ on Rietdraai 51IP close to the glacial pavements (von Backström et al., 1953), filling the northeast - southwest orientated Harts glacial valley.

To the north of Lichtenburg, within the Bakerville diamond diggings, Du Toit (1951) described the presence of Karoo sediments within the Pienaars Pothole (Ruigtelaagte 353JP). Several kilometres to the southwest in the southern part of the Carlisonia Mine (Welverdiend 361JP) there are some isolated blocks of pale red and cream coloured cross-bedded mediumgrained pebbly sandstones (Figure 5). The pebbles within these sandstones are very well-rounded and have polished surfaces. These are mainly composed of quartz, quartzite and chert, and are locally referred to as 'silkies'. These sandstones are mottled and locally bioturbated, and based on lithological similarities, have been tentatively correlated to the Upper Karoo Mosolotsane Formation in Botswana and the Lisbon Formation in the Ellisras Basin (Bordy et al., 2010). 


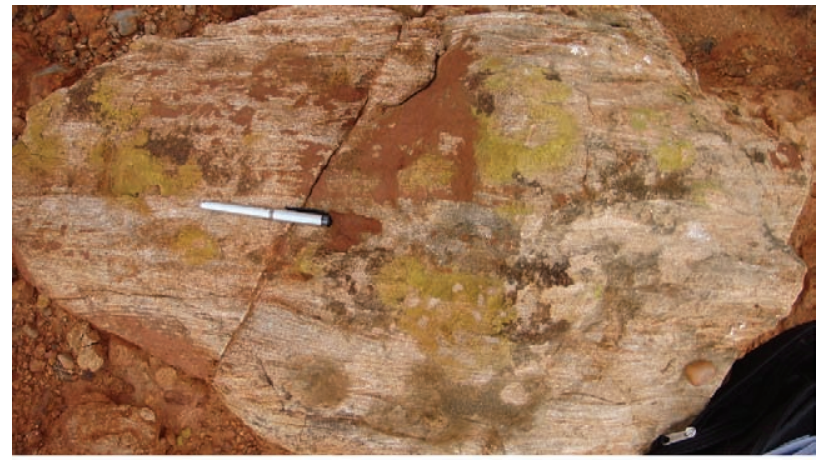

Figure 5. Cross-bedded pebbly sandstone of Upper? Karoo derivation from Carlisonia mine on Welverdiend 361JP. Locally these sediments are bioturbated and the pebbles (e.g. bottom right) are rounded and polished.

Du Toit (1951) mentioned silicified Karoo wood from Welverdiend 361JP and Ruigtelaagte 353JP, and recently a boulder size silicified wood from Pienaars pothole was recovered and identified as Karoo-age Agathoxylon (Marion Bamford, pers. comm., 2010). Harger (1928) reports the presence of fossil wood from Grasfontein 356JP and Ruigtelaagte 353JP, with a tree trunk almost $1.8 \mathrm{~m}$ in length from the former, which resembles a gymnosperm known from the Upper Karoo Molteno beds (Du Toit, 1951). Upper Karoo sediments here rest on dolomite or on Dwyka/Ecca Group sediments, much like in eastern Botswana where the Mosolotsane Formation is also underlain by a well-documented regional unconformity (Smith, 1984). Likewise, Permo-Carboniferous sediments, preserved in a karst depression south of Pretoria, are unconformably overlain by possible Upper Karoo sandstones (Wilkins et al., 1987).

On Rietpan 479JP, approximately $45 \mathrm{~km}$ east-northeast of Lichtenburg, Harger (1928) described an old shaft into ferruginised Dwyka shales underlain by dolomite. Additionally, some $20 \mathrm{~km}$ east-northeast of Ventersdorp, on the farm Ryedale 75IQ, there is a ferromanganese deposit hosted by Ecca Group shales with well-preserved imprints of Glossopteris leaves preserved in a shallow depression on the Malmani dolomite (Pack et al., 2000).

Across the Southern Field, between Schweizer-Reneke, and Klerksdorp, Von Gottberg (1970) described Karoo remnants on the exhumed pre-Karoo topography. Descriptions of glacial features, such as striated pavements, polished surfaces and roches moutonnées, indicate that the area was scoured by the Dwyka glaciation with ice moving from north to south. Dolerites have intruded clayey and unconsolidated Dwyka tillites and it was suggested that the unconsolidated nature was the result of exposure and weathering before the deposition of the overlying younger Karoo sediments (Von Gottberg, 1970), a scenario similar to the Lichtenburg/Ventersdorp area. There is also no evidence to suggest that this area was ever covered by Karoo volcanics.

The basal tillites in the southern Karoo are Carboniferous in age and the upper tillites here are correlated with the lower Ecca of the northern part of the basin and approximately equivalent to the age of the tillites in the Virginia Valley (Visser and Kingsley, 1982), which on palynological grounds is of Lower Permian age
(Anderson, 1977). Hence, the glacial beds in the Cargonian valleys are stratigraphically correlated to the top of the Dwyka further south, which implies a diachronous relationship between periods of glaciation (Visser 1987a). Since the Dwyka on the Cargonian Highland represents the final stages of this ice age, equivalent to Visser's (1997) cycle 4 of the deglaciation, this phase is of early Permian age.

The gentle sloping pre-Pretoria dolomite surface was therefore also a pre-Karoo surface scoured by the Dwyka ice, with two major valley glaciers, the Mooi and Harts (Figure 3), and some smaller valley glaciers, draining to the south and the west into the modern Vaal and Molopo drainage basins, respectively.

Black ferromanganese wad forms part of the Waterval Saprolite and is developed in strata of the Ecca Group on Ryedale 75IQ near Ventersdorp (Beukes et al., 1999). Kaolinite clay beds, derived from the original shale beds in the Karoo succession are interbedded with the wad (van Niekerk et al., 1999a). This saprolite is thought to have developed along the post-Gondwana African land surface during periods of deep humid weathering during the Late Mesozoic to early Cainozoic (Partridge and Maud, 1987; Beukes et al., 1999). Similar deposits occur on Roodepan 180IP and Houtkoppies, west and east of Ryedale 75IQ, respectively. Late Cretaceous turtle scutes and pollen were recovered from black clays at $70 \mathrm{~m}$ depth from a borehole drilled on a residual gravity low in the dolomites between Grasfontein 365JP and Elizabeth 357JP (Roger Smith pers. comm. 2016). No gravel was intersected and this low was interpreted as a sinkhole on this African surface and has erroneously been used as an age for the gravels (e.g. Partridge 1998, De Wit et al., 2000).

The African surface has been cut by the Westwits Formation, which infilled valleys incised into it as a result of uplift, and is referred to as the post-African II cycle (Partridge and Maud, 1987). Finally, overlying Hutton soils represent reworking of Kalahari sands during the post-African II cycle (Van Niekerk et al., 1999).

The timing of formation of a pedogenic manganese crust, east of Ryedale 75IQ and immediately below the post-African I erosion surface, was dated at 12 to $15 \mathrm{Ma}$ (Van Niekerk et al., 1999b). What is important to note in these sections are the geomorphological events that have prevailed from the late Cretaceous African surface to the post-Africa 11 erosion cycle some 2.5 Ma ago and reflects the prolonged period of time that this pre-Karoo surface has been subjected to surficial processes and karstification after the condensed Karoo package was partially removed.

This ancient surface on which the gravel runs have been deposited is therefore a poly-phase surface that has been shaped for at least $80 \mathrm{Myr}$ in pre-Pretoria times, some $30 \mathrm{Myr}$ in PreKaroo times, exhumed and exposed from post-Waterberg to preKaroo times and again since the Cretaceous. It contains remnants of pre-Pretoria karst and Karoo sediments, Dwyka glacial markings, evidence of the Cretaceous African land surface and younger Cainozoic erosion cycles, all at the same level. It is therefore a relatively thin surface 'layer', or a significant 'palimpsest', that represents a long history of deposition, erosion and non-deposition, but showing little evidence of denudation. 


\section{Apatite Fission Track Analysis (AFTA)}

AFTA has been used extensively to extract low temperature thermal history from rocks as they cool through the upper 3 to $5 \mathrm{~km}$ of the crust (Brown et al., 1994). The technique, when combined with the measured track length distribution (e.g. Green, 1986), has been successfully applied to constrain the magnitude and timing of crustal denudation (Jaspen et al., 2006; Wildman et al., 2015).

From AFTA of surface and borehole samples of the elevated area of the North West Province, which includes this study area, the modelled thermal history indicates that an accelerated cooling event, interpreted to reflect uplift and erosion, took place somewhere between 700 to $450 \mathrm{Ma}$ (Green et al., 2009; Mackintosh, 2013). It suggests that the Cretaceous cooling event seen along the coastal areas are not recorded in the study area (Wildman et al., 2011), and more importantly shows that there was limited cover on the pre-Karoo dolomite surface since around 300 to $350 \mathrm{Ma}$ (Figure 6).

\section{Gravel runs \\ Primary gravel}

The older or 'primary' gravels, which occur in 'runs', 'potholes' and fissure fills, have produced most diamonds - well in excess of 8 Mct. 'Potholes' is an incorrect but engrained term for sinkholes where gravels have accumulated under syn- and post-deposition karstification processes. Albert, Pienaar, Welverdiend, Cowpers, and Tirisano are some of the well known ones (Figure 2). Many occur close but not necessarily within the gravel runs. The fissure fills are deep, narrow and linear structures infilled with gravel and generally bounded by almost vertical dolomite walls. Examples are found on Grasfontein 356JP (King, Malan, Van Wyk) and Goedvooruitzicht 120IP.

The runs are listed in Table 1, and vary from 3 to over $30 \mathrm{~km}$ in length; they are some $70 \mathrm{~m}$ wide on average but can be as wide as $500 \mathrm{~m}$ in isolated areas. The runs are positive features of up to $20 \mathrm{~m}$ high that are best developed in the Lichtenburg area. In the Venterdorp area there is more incision into the dolomite bedrock

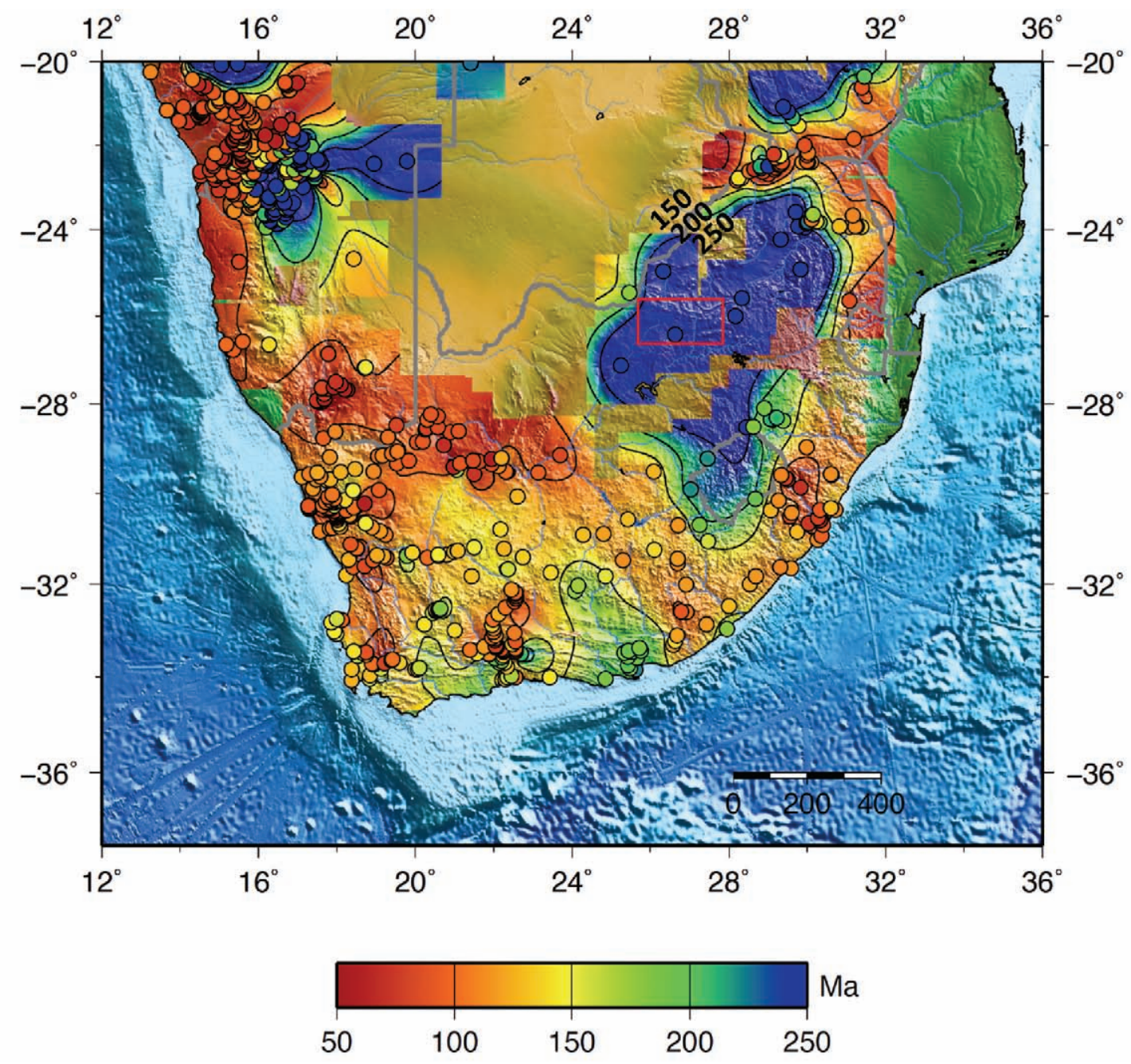

Figure 6. Map showing the pattern of apatite fission track ages determined from surface samples across southern Africa (after R Brown and $M$ Wildman). Locations of samples are shown by the filled circles (coloured by age) and the age contours are 50 Myr intervals as shown on the legend. The location of the study area is indicated by the red rectangle. Note that the measured fission track ages, on its own, only provide a qualitative and relative indication of the depth of erosion during the Mesozoic (olderages indicate less erosion and younger ages indicate deepererosion). 
EARLY PERMIAN DIAMOND-BEARING PROXIMAL ESKERS IN THE LICHTENBURG/VENTERSDORP AREA OF THE NORTH WEST PROVINCE, SOUTH AFRICA

Table 1. The 'runs' in the Lichtenburg/Ventersdorp area and the respective diamond recoveries (carats and value). Farms from which the diamonds were reported and famous 'potholes' are listed for each run.

\begin{tabular}{|c|c|c|c|c|c|}
\hline \multicolumn{6}{|l|}{ Primary Gravels } \\
\hline & Farms & Potholes & Carats & Rands & $\mathbf{R} / \mathbf{c t}$ \\
\hline Zeerust & $\begin{array}{l}\text { Tweefontein, Kafferskraal, Doornplaat, } \\
\text { Olifantsfontein }\end{array}$ & & 525.49 & 6160.00 & 11.72 \\
\hline Bakerville Run & $\begin{array}{l}\text { Klipkuil, Ruigtelaagte, Uitgevonden, } \\
\text { Grasfontein, La Reystryd, Hendriksdal, } \\
\text { de Paarl, Houthaaldoorns }\end{array}$ & $\begin{array}{l}\text { Van Wyks, Pienaars, } \\
\text { Gravitatie, S1 }\end{array}$ & 5453394.07 & 29807008.00 & 5.47 \\
\hline Vlakplaats Run & Wonderfontein, Vlakplaas, Honingklip & Cowpers & 80128.05 & 314672.00 & 3.93 \\
\hline Elizabeth Run & Trekdrift, Elizabeth & Alberts & 114296.45 & 727150.00 & 6.36 \\
\hline Grasfontein deposit & Sheet gravels on Grasfontein & $\begin{array}{l}\text { Kings, Malans, Van } \\
\text { Wyks }\end{array}$ & & & \\
\hline Welvediend deposit & Welverdiend & Carlisonia mine & 1577957.37 & 5723319.00 & 3.63 \\
\hline Pypklip deposit & Pypklip & & 18927.75 & 574977.00 & 30.38 \\
\hline Lichtenburg Run & Lichtenburg Township & & & & \\
\hline Manana Run & Witklip, Klipbankfontein & & 229356.18 & 2189696.00 & 9.55 \\
\hline Witstinkhoutboom Run & $\begin{array}{l}\text { Doornkop, Hollaagte, } \\
\text { Witstinkhoutboom, Roodepan, Vlakpan }\end{array}$ & & 2257.75 & 9591.00 & 4.25 \\
\hline Schilpadverdriet Run & Schilpadverdriet & & 1145.00 & 10327.00 & 9.02 \\
\hline Twee Buffels Run & $\begin{array}{l}\text { Goedvooruitzicht, Klippan, } \\
\text { Roodepoortje, Twee Buffels, } \\
\text { Sterkfontein, Putfontein, Holgat, } \\
\text { Omega, Wildfontein }\end{array}$ & & 157370.64 & 3292723.00 & 20.92 \\
\hline Vogelstruispan Run & $\begin{array}{l}\text { Zwartrand, Kwaggas Laagte, Houtkop, } \\
\text { Vogelstruispan, Boschkop, Polka }\end{array}$ & & 6841.20 & 608861.00 & 89.00 \\
\hline Nooitgedacht Run & $\begin{array}{l}\text { Witkrans, Nooitgedacht, Bultfontein, } \\
\text { Haartbeeslaagte, Zwartrand, } \\
\text { Welgevonden, Appeldraai }\end{array}$ & Tirisona mine & 37593.32 & 1267241.00 & 33.71 \\
\hline Zwartplaas Run & $\begin{array}{l}\text { Zwartplaat, Droogepan, Leeuwkraal, } \\
\text { Bruidegomskraal, Roodepan, Uikyk }\end{array}$ & & 229445.72 & 4013329.00 & 17.49 \\
\hline Illmasdale Run & $\begin{array}{l}\text { Avondson, Morgenson, Illmasdale, } \\
\text { Wildebeeslaagte, Ryedale, Oatlands }\end{array}$ & & 20701.01 & 202936.00 & 9.80 \\
\hline Goedgedacht Run & $\begin{array}{l}\text { Elandsfontein, Klipgat, Goedgedacht, } \\
\text { Buchansvale, Leeuwpan, Rooipan }\end{array}$ & & 81976.08 & 1878299.00 & 22.91 \\
\hline Holfontein Run & Holfontein & & 38632.50 & 552458.00 & 14.30 \\
\hline
\end{tabular}

\section{Reworked deposits}

Mafikeng deposit

Mooi River terraces

Rietspruit

Taaibosspruit
Mined from 1986 to 1992 ;

US\$, \$/ct $(0.5 \mathrm{ct} / \mathrm{st})$

Bovenste oog, Klerkskraal,

Varkenskraal, Rooiwal, Zamenkomst,

Reimierbult, Rooidraai, Rietvalley,

Rooidraai, Rietvallei, Thyszyndoorns,

Muiskraal (2x), Dutoitspruit, Kiel,

Katdoornbosch, Gerhardminebron,

Buffelsvlei, Witkoppies. Elandsheuvel,

Potch Townlands, Haaskraal, Elbrinxen

Oog van schoonspruit, Elandskuil,

Klipplaatsdrift, Sterkstroom,

Buffelsvallei, Witpoort, Beentjieskraal,

Elandsheuvel, Klerksdorp Town,

Nooigedacht, Zwartkoppies,

Goedgenoeg

Kaalfontein, Vlakfontein

Klipfontein, Rietfontein
17863.47

228837.00

\subsection{4}

$7628696.00 \quad 204.28$

159251.68

3842541.00

24.13

$43151.00 \quad 13.68$

\begin{tabular}{rrr}
3153.25 & 43151.00 & 13.68 \\
82.75 & 458.00 & 5.53 \\
\hline
\end{tabular}


but chains of lower elevation have been described (Du Toit, 1935). The gradient and morphology of the $29 \mathrm{~km}$ long Twee Buffels run, the only one which partially covers Ventersdorp bedrock, remains unchanged across the contact between the Malmani dolomites and the Ventersdorp lava. This shows that the gravels did not protect the underlying dolomite rock from a general lowering of the dolomite surface by solution processes, and thereby transforming incised channels within the dolomite to elevated ridges or runs, previously referred to as 'inverted topography' (e.g. Du Toit, 1951).

The main lithofacies encountered in the 'older gravels' in the runs and potholes are summarized in Table 2. The gravels are mainly coarse-grained, poorly-sorted, both matrix- and clastsupported and contain angular to well-rounded clasts. In the Lichtenburg area they have been classified as very poorly-sorted coarse-muddy gravel (Stettler, 1979), while those in the Ventersdorp area as coarse-grained, poorly-sorted with clayey matrix (Marshall and Norton, 2009). The term diamictite is appropriate as it refers to any poorly sorted clast-sand-mud admixture regardless of depositional environment (Eyles et al., 1983), and a coding system was introduced to cover these lithofacies (Table 2).

The presence of muscovite as a large component in the clay fraction (section 6) and the absence of feldspar in Dwyka Group sediments in the northern part of the Karoo Basin (Bühmann et al., 1990) indicates that the clay fraction is mostly primary in these older gravels.

\section{Tectonised bedrock}

The altered Malmani bedrock, which has been modified by glacial activity, can also be subdivided into three main facies types (Table 2). Firstly, there is in situ shattered and fractured bedrock with associated closely packed bedrock breccia (BBcsh), such as exposed in the old Welverdiend workings (Figure 7a). Secondly, there are bedrock breccias (BBm), with locally derived and randomly orientated angular clasts and generally devoid of any bedrock macrofabric, which grade upwards into the Dmm/Dcm facies (Figure $7 \mathrm{~b}$ ) with a decrease in size and frequency of bedrock clasts and an increase proportion of foreign clasts. Matrix is fine-grained and quartzrich with some kaolinite. Thirdly, some folded bedrock breccia $(\mathrm{BB}(\mathrm{t})$ ) of mainly chert grading into Dcm diamictite composed of highly concentrated angular bedrock clasts with shattered chert rafts are seen in the more elevated section on the Lichtenburg Townlands, for instance (Figure 7c). The bedrock breccias are not to be confused with the silicified chert breccias from the Rooihoogte Formation, or with the altered and manganiferousrich breccias that are part of the karstification process of the dolomites

\section{Gradients of the gravel runs}

Elevation data were collected along the main gravel 'runs' at approximately every $100 \mathrm{~m}$ in order to establish the average gradients of these features. These data were based on SRTM data, (a)
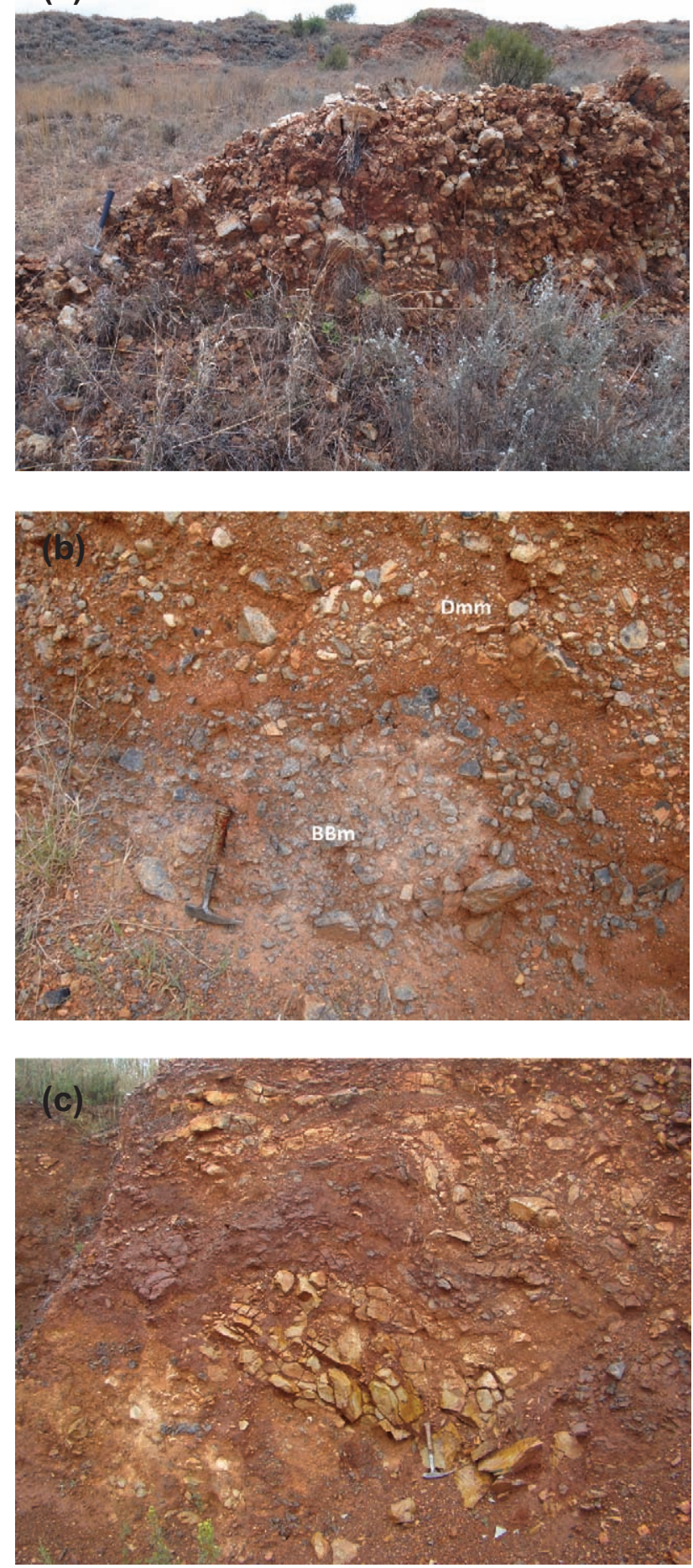

Figure 7. (a) In situ shattered bedrock breccia, with high density of chert fracturing and little or no displacement, directly below the gravel deposit on Welverdiend 361JP (facies BBsch). This shattering is interpreted as the result of frost action. Hammer for scale. (b) Bedrock breccia (BBm) overlain by matrix-supported diamictite (Dmm) in the Manana run. Hammer for scale. (c) Layered bedrock residue deformed by locally developed folds and shattered bedrock rafts interpreted as glacitectonic structures (BB(t)facies). Hammerfor scale. 
EARLY PERMIAN DIAMOND-BEARING PROXIMAL ESKERS IN THE LICHTENBURG/VENTERSDORP AREA OF THE NORTH WEST PROVINCE, SOUTH AFRICA

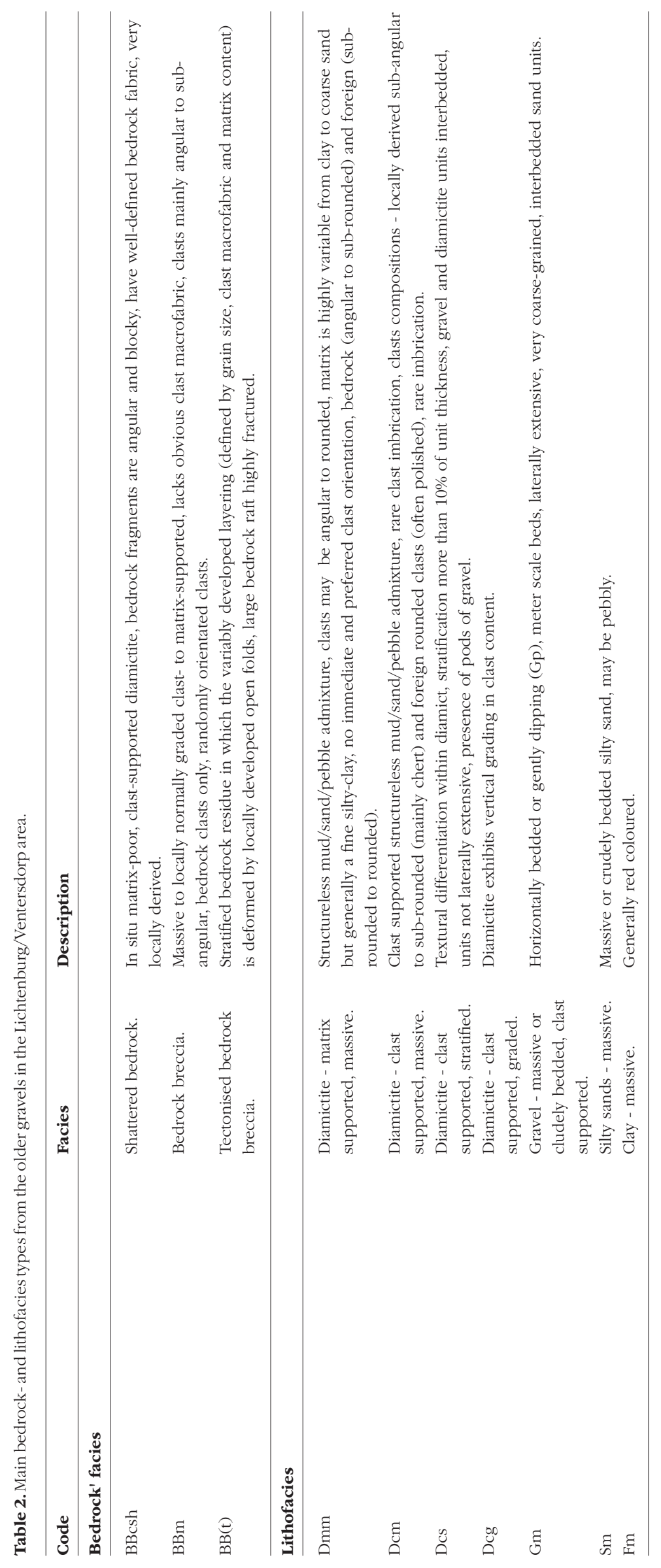


1:50 000 scale topocadastral maps and 1: 10000 scale orthophotos. Although accuracies varied from 5 and $30 \mathrm{~m}$ depending on the dataset used, it nevertheless provides sufficient detail to establish average gradients along the profile of these runs (Table 3). All the gravel runs have gradients less than $1.6 \mathrm{~m} / \mathrm{km}$ and several significantly so. Furthermore, the Goedgedacht run has an average gradient of zero and the Vlakplaats and Illmasdale runs have negative average gradients $(-0.14$ and $-0.45 \mathrm{~m} / \mathrm{km}$, respectively) indicating that these southward directed runs were 'flowing uphill'.

The average gradients of most of the runs can be classified at the lower-end of gentle, with two almost flat, one as flat and two as negative (Leveson, 2002). In addition, the Bakerville, Vlakplaats, Manana, Goedgedacht (Figure 8), and Illmasdale gravel runs have sections where the gradient is negative (Table 3). The Vlakplaats run, for instance, rises by some $20 \mathrm{~m}$ over a distance approximately $3.5 \mathrm{~km}$ before intersecting the Bakerville run, which itself rises by some $8 \mathrm{~m}$ over a distance of $3 \mathrm{~km}$ 'upstream' of this intersection; the Manana run rises with some $10 \mathrm{~m}$ over the first $1.5 \mathrm{~km}$; the Schilpadverdriet run is almost flat over the lower $1.3 \mathrm{~km}$ of its length; the Twee Buffels run rises by a few metres over its lower $4.1 \mathrm{~km}$ section; the upper $3 \mathrm{~km}$ of the Illmansdale run rises almost $63 \mathrm{~m}$ and after a distance of $7 \mathrm{~km}$ it is at the same elevation as at its starting point; the Goedgedacht run climbs $35 \mathrm{~m}$ over the first $2.5 \mathrm{~km}$ of its course; and the Nooitgedacht run rises some $7 \mathrm{~m}$ over more than $4 \mathrm{~km}$ in the middle section. Although subsidence has been observed in $3 \mathrm{D}$ on a local scale due to karstification, the sinkholes are limited in size and there is no evidence to suggest that this occurs over several $\mathrm{km}$. As pointed out by Du Toit (1933) the southward-dipping surface seems unaffected by regional tectonics. Even where the gradient is

Table 3. Length and average gradient for each run. The start and finish of each run are listed by farm name.

\begin{tabular}{|c|c|c|c|}
\hline \multicolumn{4}{|l|}{ Primary gravels } \\
\hline & $\begin{array}{l}\text { Length } \\
(\mathbf{k m})\end{array}$ & $\begin{array}{c}\text { Farms: start } \\
\text { to finish }\end{array}$ & $\begin{array}{c}\text { Average } \\
\text { gradient } \\
(\mathbf{m} / \mathbf{k m} \text { or } \%)\end{array}$ \\
\hline Bakerville Run & 30.8 & Pypklip - La Reystryd & 1.01 \\
\hline Vlakplaats Run & 14.8 & Geluksdal - Bakerville & -0.14 \\
\hline Manana Run (only) & 7.6 & $\begin{array}{l}\text { Lichb. Reserve - } \\
\text { Manana }\end{array}$ & 0.53 \\
\hline $\begin{array}{l}\text { Witstinkhoutboom } \\
\text { Run }\end{array}$ & 4.5 & $\begin{array}{l}\text { Witstinkhoutboom - } \\
\text { Roodepan }\end{array}$ & 0.22 \\
\hline $\begin{array}{l}\text { Schilpadverdriet } \\
\text { Run }\end{array}$ & 2.9 & Schilpadverdriet & 1.38 \\
\hline Twee Buffels Run & 28.9 & $\begin{array}{l}\text { Goedvooruitzicht - } \\
\text { Wildfontein }\end{array}$ & 1.63 \\
\hline Nooitgedacht Run & 8.8 & $\begin{array}{l}\text { Nooitgedacht - } \\
\text { Zwartrand }\end{array}$ & 1.48 \\
\hline Zwartplaas Run & 17.7 & Zwartpaas - Uitkyk & 1.13 \\
\hline Illmasdale Run & 11.2 & Avondson - Oatlands & -0.45 \\
\hline Goedgedacht Run & 11.7 & Klipgat - Buchansvale & 0 \\
\hline \multicolumn{4}{|l|}{ Reworked deposits } \\
\hline Mafikeng deposit & 3.1 & & 6.25 \\
\hline Mooi River terraces & 31.2 & $\begin{array}{l}\text { Klerkskraal dam - Du } \\
\text { Toitspruit }\end{array}$ & 1.96 \\
\hline
\end{tabular}

negative towards the south, i.e. in a downstream direction, the gravel runs have remained unchanged, requiring an alternative explanation for the uphill flow of these gravel runs.

\section{Individual runs}

The Bakerville run is over $25 \mathrm{~km}$ long from Klipkuil 352JP in the east to La Rey Stryd 53IO in the west (Table 2). Isolated diggings occur on Pypklip 362JP as an eastern extension of the Bakerville run and on Welverdiend 361JP, with its famous Carlisonia Mine, which is $2 \mathrm{~km}$ south of the eastern part of the Bakerville run. The run has a west-southwest orientation. It varies in width from less than $150 \mathrm{~m}$ in the east, to $500 \mathrm{~m}$ in the central area and down to $200 \mathrm{~m}$ in the west. In the east, between Peinaars pothole and Pypklip, the digging area is marked by a straight narrow 'fissure' almost $5 \mathrm{~km}$ in length and less than $50 \mathrm{~m}$ wide (Figure 9). Pienaars pothole on Ruigtelaagte 353JP, which has produced well over 0.5 Mct of diamonds, occurs off-set from the main Bakerville run but is connected to it via the S1 and S2 sinkholes. These are located on a northeast-orientated fracture (Figure 9) filled with gravels almost $1 \mathrm{~km}$ in length and $200 \mathrm{~m}$ wide (Stettler, 1979). Pienaars itself is situated on the intersection of two gorge-like leached zones (Stettler, 1979).

The Bakerville run connects with the southwest-orientated Vlakplaats run in the south-western corner of Uitgevonden 355JP. According to Du Toit (1951) there is no age difference between these two branches. Interestingly, the diamonds from the Vlakplaats run are of lower value that those from Uitgevonden 355JP and Grasfontein 356JP (Du Toit, 1951; Marshall, 1987). The combined run is continuous towards the west-southwest but there is an expanse of shallow diggings over much of Grasfontein 356JP. Kings fissure fill occurs to the north of the main run and within this expanse. It comprises a narrow 'fissure' no more than $15 \mathrm{~m}$ wide and is defined by almost vertical dolomite cliffs. It has a north-south orientation over a distance of some $150 \mathrm{~m}$. Strong ground water prevented the excavation below $45 \mathrm{~m}$ depth. The material at this depth is described as a greyish calcareous clay carrying pale green chert pebbles and agates (Du Toit, 1951). In the south of this expanse and just north of the Bakerville run is Malans fissure fill, orientated towards the east-northeast. Less than $1 \mathrm{~km}$ to the west is Van Wyks (or MSG) fissure fill, which has a similar orientation as Kings. This pothole expressed itself as a large (- 1.7 mgal) gravity anomaly and drilling has shown this to contain a large amount of unworked gravel (De Wit, 1981).

Textural analysis for samples collected from the upper and lower parts of the gravels along the Bakerville run have shown these to be bi-modal, although the latter have a much clearer bi-modal signature (Stettler, 1979). The overall mean grain size defines it as a very-coarse (pebble) gravel that is generally matrix-supported. The lower gravel was classified as a coarse-muddy gravel and the upper gravel as a coarse-muddysandy gravel (Stettler, 1979). Both are very poorly- to extremely poorly-sorted according to Folk's (1968) classification and described as diamictite Dcm and Dmm lithofacies. Carnelians and chalcedonies are common in Pienaars and surrounding diggings. 


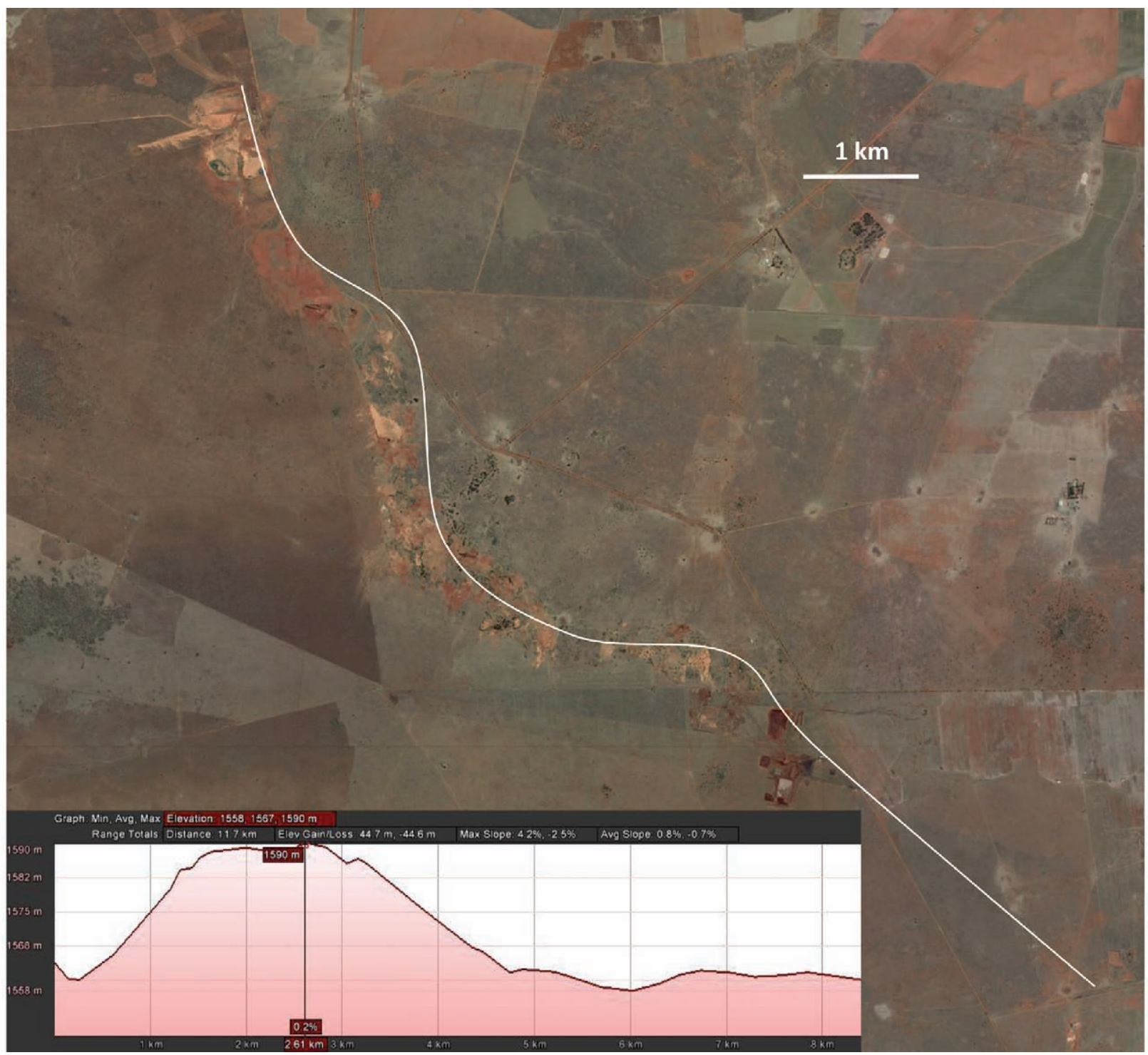

Figure 8. Profile of the Goedgedacht 'run' showing the major uphill section in the upperpart of the run as well as its overall zero gradient (Google image as background).

Between the Bakerville $(30.8 \mathrm{~km})$ and Twee Buffels $(28.9 \mathrm{~km})$ runs, are four shorter runs all orientated almost northsouth. These are from west to east the Lichtenburg $(3 \mathrm{~km})$, Manana ( $7 \mathrm{~km}$ ) Witstinkhoutboom ( $4 \mathrm{~km})$, and Schilpadverdriet $(3.5 \mathrm{~km})$ runs (Table 1$)$. Together these have produced nearly $270,000 \mathrm{ct}$, most of which $(230,000 \mathrm{ct})$ have come from the Manana run. The presence of Rooihoogte conglomerate and Pretoria Group quartzite clasts in the gravels suggests that the source area was to the north. This is supported by the distribution of andalusite minerals in the soils in the Lichtenburg district, derived from hornfelses located north-east of Zeerust and Swartruggens, which decrease in concentrate and increase in roundness in a southerly direction (Mayer, 1985).

The Manana run is $7 \mathrm{~km}$ long and is orientated towards the south-south-east. The diggings start in a large depression west of the road from Lichtenburg to Welverdiend. The run then swings to the south-southeast and attains a width of between 100 and $150 \mathrm{~m}$ over most of its length. It thins in the south where it terminates on dolomite just before the Karoo outlier east of Lichtenburg. The gravel is mainly composed of subangular blue chert, some oolitic, and rounded pebbles of red quartzite, green/grey and black chert and vein quartz. No agates were found. The quartzites are mainly derived from the Pretoria Group to the northeast. Texturally the gravel is a massive, poorly-sorted clast- and matrix- supported diamictite (Dmm and $\mathrm{Dcm}$ ) with a matrix of maroon-coloured clay (Figure 10). It is underlain and grades into a chert breccia (BBm) and blocks of weathered chert.

The Witstinkhoutboom run is some $80 \mathrm{~m}$ wide and diamonds are small and very patchy (Du Toit, 1951). Clasts are mainly composed of black and blue chert, red quartzite and vein quartz. The chert is generally subangular while the quartzite and vein quartz pebbles are subrounded. Only one possible, but highly altered, agate was found. The rounded chert and vein quartz clasts are scarred by high concentrations of percussion marks (Figure 11).

The Schilpadverdriet run is only $2.9 \mathrm{~km}$ long and relatively shallow. The basal part overlies an irregularly shaped chert 


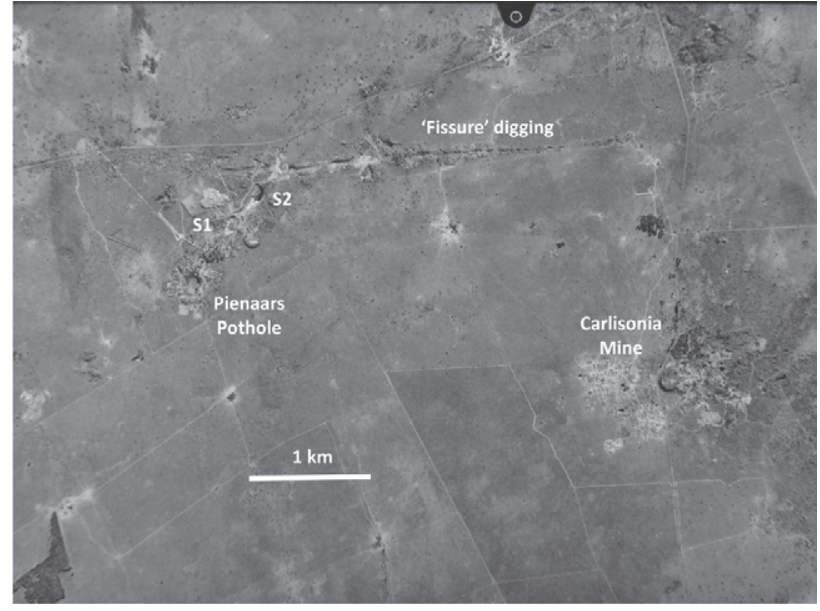

Figure 9. Areal photograph (2002) of Pienaars pothole area highlighting the almost east-west gravel-infilled structured.

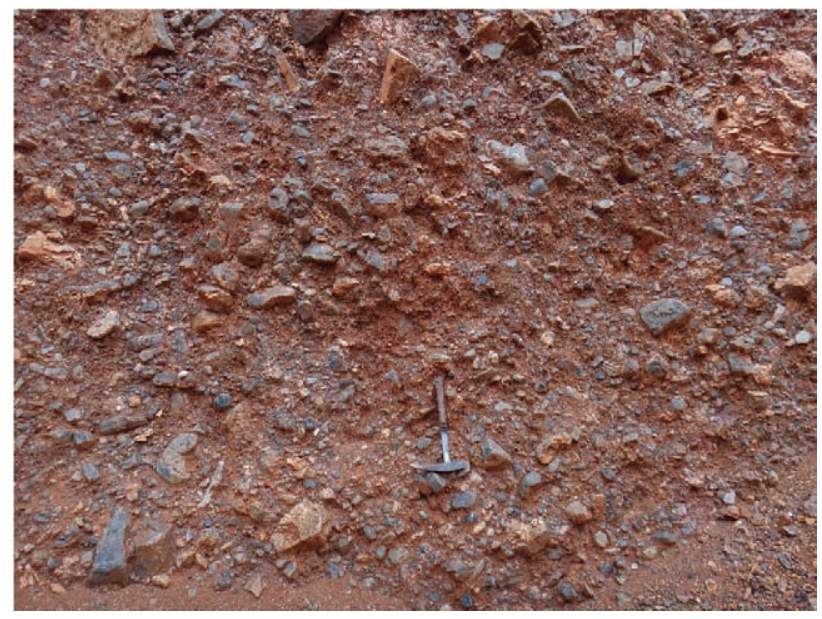

Figure 10. Clast-supported massive diamictite (Dcm) lithofacies from the Manana run. Note the shape variations of the clasts. Hammer for scale.

breccia $(\mathrm{BBm})$, which forms pinnacles. Angular clasts are almost entirely chert. This is overlain by a clast-supported and poorlysorted boulder diamictite $(\mathrm{Dcm})$ and with clasts that have no preferred orientation. The subangular to subrounded clasts are mainly red quartzite, blue chert and vein quartz. Many of these boulders have percussion scars. The vein quartz clasts are derived from a north-south orientated $30 \mathrm{~m}$ wide quartz vein overlain by the gravel run. Here the vein is polished and scarred by percussion marks. The western edge of the run is a finer grained, slightly better sorted, pebble-size diamictite (Dcm) and is covered by an upper indurated dark brown matrix-rich diamictite with isolated pebbles (Dmm). Like the Manana and the Witstinkhoutboom runs, the Schilpadverdriet runs terminate just before the cultivated fields underlain by the outlier of Lower Karoo sediments, east of Lichtenburg.

The Twee Buffels run starts on the farm Rietpan 479JP close to an area of cultivated lands underlain by Karoo where Harger (1928) described Karoo shales. Gravels here and to the south on Ga-Motlatla (Kwaggaslaagte 121IP) are poorly exposed. In the south this $29 \mathrm{~km}$ long run terminates abruptly on Black

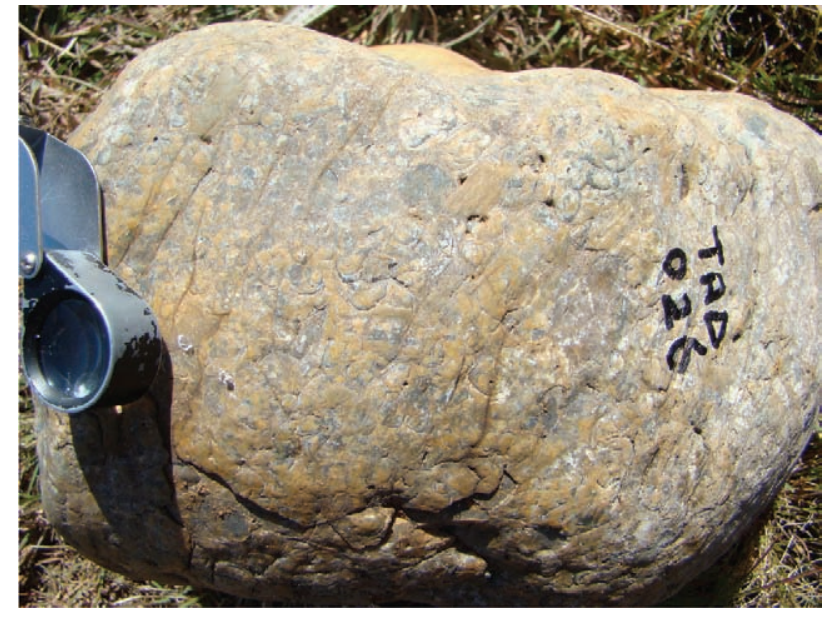

Figure 11. Boulder of Rooihoogte Formation conglomerate covered with percussion scars from Omega 1561 in the Twee Buffels run. Hand lens forscale.

Reef shales on Wildfontein 201IP at the edge of the ancient dolomite surface. Below this edge the slope increases considerably towards the palaeo-Ecca shoreline and no runs are present here.

The Twee Buffels run has produced close to 160,000 ct up to 1984 (Marshall, 1987). Most of the production came from Putfontein 62IP, where intense mining activities took place between 1923 and 1926 (Du Toit, 1951). In the northern parts of this run the rounded pebbles and boulders are composed of grey and red coarse-grained quartzite, cross-bedded blue quartzite, white quartzite and chert-pebble (well-rounded, poorly-sorted) conglomerate of the Rooihoogte Formation. The quartzites are mainly derived from other units in the Pretoria Group and the source of these gravels was therefore to the northeast. No agates were found.

The coarse boulder gravel is generally clast-supported. Like in some of the other runs, the surfaces of most pebbles and boulders are marked with high concentrations of percussions scars (Figure 11), a reflection of the intense level of clast to clast collisions and even some sub-angular to sub-rounded locally derived chert clasts have percussion scars. Local operator P. Le Roux (pers. comm. June 2010) found that there is a high percentage broken diamonds from these areas. Where the run overlies the Ventersdorp Supergroup on Twee Buffels 42IP, the quartzite floor is also scarred by percussion marks. The gravel here is thin (less than $1 \mathrm{~m}$ ) and loosely cemented by manganocrete and at the end of the run there is a manganese nodular soil directly on weathered Ventersdorp bedrock.

The north-south orientated Vogelstruispan run starts $3 \mathrm{~km}$ east of the top end of the Twee Buffels run on Zwartrand 123IP and Houtkop 152IP. Isolated excavations from Houtkop 152IP to Vogelstruispan 151IP contain clasts predominantly composed of green/blue chert, sub-angular but with scars, and sub-rounded black chert, oolithic chert, vein quartz, and white and brown quartzite. No agates nor chert breccia clasts were seen. This run also originates from the red soil covered area on Rietpan 479JP. The gravels of this much shorter run have produced nearly 7,000 ct (Table 2) mainly from the northern end on Zwartrand 123IP (Marshall, 1987). 
The Nooitgedacht run has been mined until more recently on a larger than artisanal scale by several companies. Up to 1984 three properties along this run, Nooitgedacht 131IP, Hartbeeslaagte 146IP and Zwartrand $145 \mathrm{IP}$, produced $36,863 \mathrm{ct}$ (Table 1). Since the early 1990s and up to 2012 it has produced an additional 47,033 ct (Company reports Etruscan Resources Inc., Rockwell Diamonds Inc. and Transhex Group Ltd.).

The gravels have been subdivided into several units, but the most important are the lower gravel package (LGP), followed by a small-pebbly clay package with sand lenses (PCP) and the upper gravel package (UGP) (Marshall and Norton, 2009). In the deeper parts of the main depression and below the LGP there is a basal gravel package dominated by rounded clasts of white to grey quartzites. The LGP is generally clast-supported with a reddish-brown clay matrix (Dcm lithofacies), but becomes matrix-supported and more clay-rich in the upper part (Figure 12) where it is referred to as the transition zone package (TZP).

The main components are locally derived chert, wellrounded Pretoria Group quartzite and the LGP contains red Waterberg Group clasts (Marshall and Norton, 2009). The intermediate PCP unit comprises clays (white to light yellow in colour) and pebble to small cobble lenses. The UGP is generally coarse-grained, poorly-sorted and clast-supported, and the matrix is a yellow-brown clay (Marshall and Norton, 2009). The clasts in the LGP are generally well-rounded while those in the UGP are both rounded and angular, especially the chert. Parts of the UGP are stratified with large horizontal meter-scale and low-angle gravel beds ( $\mathrm{Gm} / \mathrm{Gms}$ ) (Figure 13). The diamond grades of the LGP are around $1.2 \mathrm{cpht}$, while that of the UGP is 0.7 cpht (Marshall and Norton, 2010). A large part of the LGP and PCP gravels have been preserved in a depression at the intersection of two major structures and is overlain by a sandy clay that extends beyond the confines of the sinkhole. The UGP occurs on the western shoulder, spreading beyond the depression as sheet gravels.

The Zwartplaas run can be followed for $17.7 \mathrm{~km}$ from Zwartplaas 176IP to Uitkyk 184 IP and from discovery to 1984 it produced 229,445 ct (Table 1). LGP- and UGP-type gravels have been mapped on Zwartplaas 176IP and UGP-type gravels have been recorded on Bruidegomskraal 178IP (Marshall and Norton, 2009).

The Illmasdale run can be followed from Avondson 71IQ, through Illmansdale 70IQ, to Oatlands a distance of some $11.2 \mathrm{~km}$. Up to 1984 these properties produced just over 20,000 ct (Table 1)

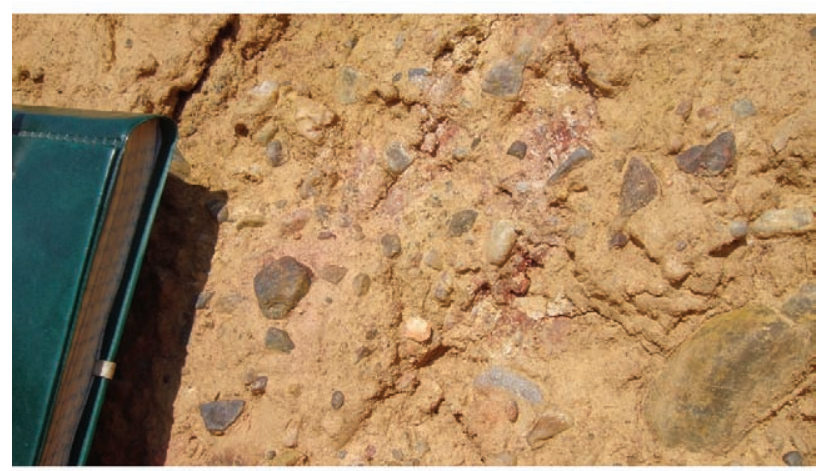

Figure 12. Clay rich matrix-supported diamictite (Dmm) lithofacies at the Tirisona mine. Notebookfor scale. mainly from LGP gravels on Krugersdal 5IQ, Morgenzon 9IQ and Illmasdale 70IQ with grades close to $1.3 \mathrm{cpht}$ (Marshall, 2010). UGP gravels have also been mapped on Krugersdal 5 IQ and Morgenson 9IQ.

The farm Klipgat 18IQ is located on the northern most portion of the Goedgedacht run, which has been worked extensively over the past 75 years and up to 1984 produced some 82,000 ct (Table 1). The projected run from Klipgat 18IQ to Buchansvale 61IQ covers a distance of nearly $12 \mathrm{~km}$, but the northwest-southeast trending section on Klipgat 18IQ is $2 \mathrm{~km}$ long and composed of a series of adjoining and interlinking potholes, generally between 80 and $120 \mathrm{~m}$ across. The gravels here are concentrated in isolated steep-sided channels that are structurally controlled (Marshall and Norton, 2010). The basal LGP gravel is a clay-poor boulder-size gravel with ochre coloured argillaceous matrix (Dcm lithofacies) that is typically $5 \mathrm{~m}$ or more thick with diamond grades of around $1.3 \mathrm{cpht}$. This is overlain by a clay-rich red-coloured PCP-type gravel unit which is almost barren. The UGP gravels ( $\mathrm{Gm} / \mathrm{Gms}$ ), believed to be reworked gravels and with highly variable grades, form more continuous sheets (Marshall and Norton, 2010). Mining operations on Goedgedacht 27IQ, adjacent to Klipgat 18IQ, were initially concentrated on two potholes, the larger of which is at least $100 \mathrm{~m}$ in diameter and mined down some 10 to $15 \mathrm{~m}$. The deposit comprises a low-grade sandy clay layer overlain by the productive gravels with a grade of $1.7 \mathrm{cpht}$ (Marshall, 2010).

The most easterly known run, the Holfontein run, is only some $2 \mathrm{~km}$ in length orientated almost east-west. Up to 1984 it produced a total of some 38,600 ct (Table 1) but operations only stopped in 2012. LGP gravels are the main source of the diamonds on Holfontein. It is also the home of the largest abraded agates (Du Toit, 1951) of all the runs.

\section{Clay mineralogy}

Marshall and Norton (2009) report XRD analyses of samples taken from the LGP, TZP and UGP gravel units on the Nooitgedacht run north of Ventersdorp (Table 4). These are all broadly similar, with quartz (50 to $60 \%$ ), kaolinite (20 to 30\%), goethite (10 to 15\%) and mica (10 to $11 \%$ ) making up the predominant phases. Samples from other runs and deposits (Robb, 1994) have a similar make-up, with quartz, goethite, muscovite and kaolinite as the main components (Table 4). Interestingly, muscovite is also a major component in Lower Karoo sediments in the Bothaville area (Bühmann et al., 1990) and the presence of kaolinite has been reported in the Middle and Upper Vryheid Formation (Ecca Group) sediments (Bredell, 1978; Bühmann et al., 1990). In fact, all known refractory clays (mainly kaolinite) occur in the Vryheid Formation along the northern edge of the main Karoo Basin (Bredell, 1978). It is also dominant in the Permian Ryedale ferromanganese deposit (Pack et al., 2000) and in the Karoo of Pienaars pothole (Du Toit, 1951). It is suggested that kaolinite in Permian sediments was early diagenetic or post-depositional (Bühmann et al., 1990) and formed under the influence of acid (freshwater) and not marine porewaters (Bühmann et al., 1990). The survival of muscovite in many of the gravel samples suggests that these sediments were 


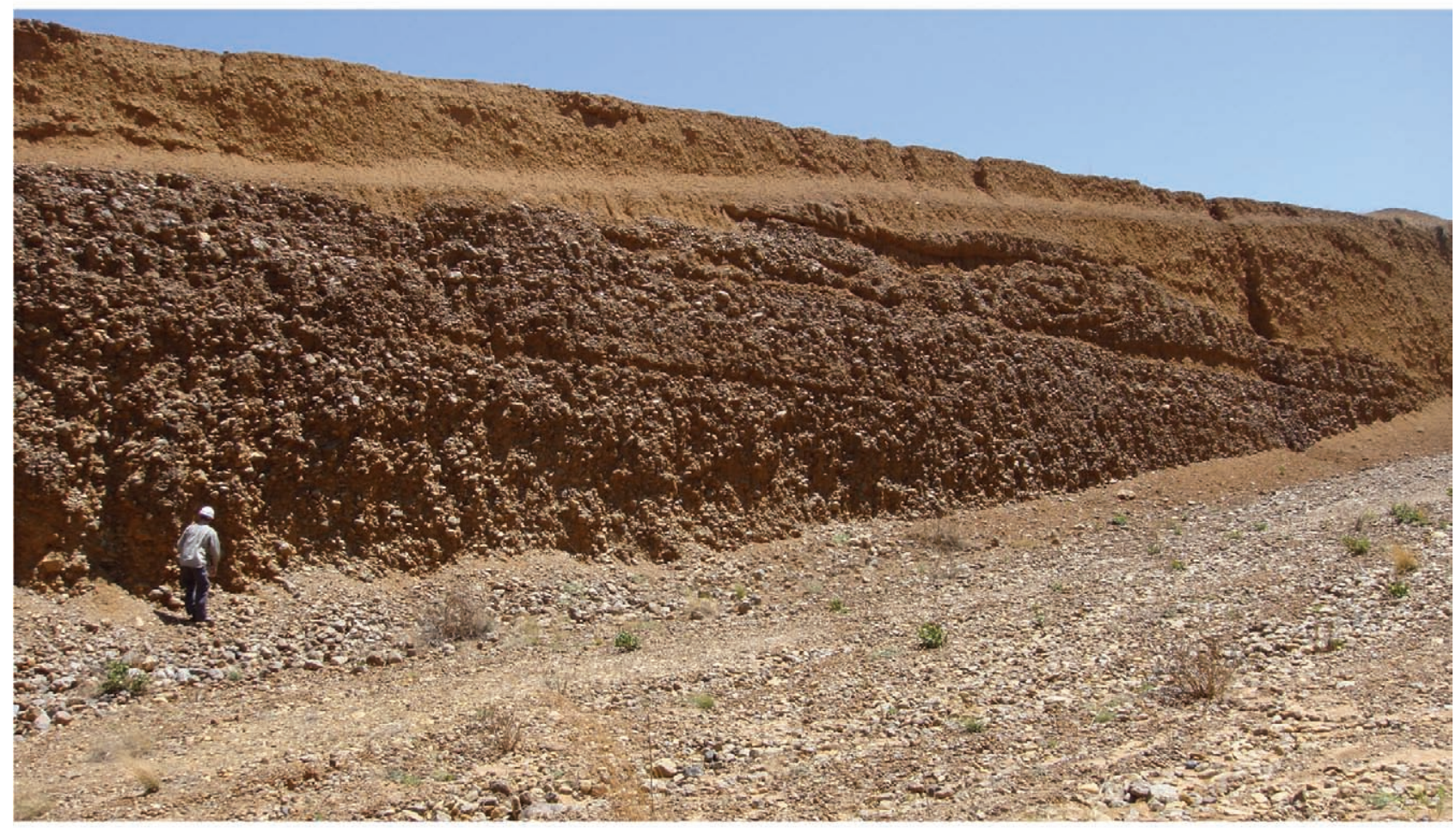

Figure 13. Massive or crudely bedded gravel (Gm) lithofacies with low angle or horizontal stratification from the upper section at the Tirisano Mine. Dipping to the south, thesefacies represent outwash facies. Man for scale.

not exposed to intense weathering during and after deposition. The clay mineralogy of the gravels is, therefore very similar to that of the Lower Ecca Group sediments. The presence of goethite and heamatite can be ascribed to the groundwater remobilizing of Iron and manganese from the Malmani dolomites (Pack et al., 2000).

Several samples mainly of red clay from Lichtenburg (Figure 14), and particularly from some of the potholes, have a high proportion of smectite (Table 4), which is often associated with the weathering of mafic rocks such as basalts (Eggleton et al., 1987), and these clays are likely weathered sources for the unabraded amygdales.

\section{Agates}

There are two populations of agate in the Northern and Eastern Fields. Firstly, there are the wine-coloured carnelians and yellow chalcedonies that are restricted to certain potholes (e.g. Welverdiend, Pienaars, Kings etc.) and runs north of Lichtenburg, and are not seen in the Eastern Field. According to Du Toit (1951), the colours are due to staining by fluids enriched in iron and manganese derived from the weathered surrounding materials, and as suggested that the red clay (Figure 14) in which some agates occur might be relics of weathered lava. Importantly, the carnelians and chalcedonies are generally unabraded and have fresh surface textures, also described by Du Toit (1951). Pipe carnelians are common, and especially within the deeper 'potholes'.

Secondly, pale coloured agates are generally banded with white, grey and black colours. These are mainly well-rounded and highly abraded with smooth surfaces, and are found in most of the gravels in the Northern and Eastern fields, but in lower and more variable concentrations.

Since the source areas of the gravels is to the north, the Ventersdorp Supergroup as a source for the agates can be ignored and the most likely sources for the agates are the two units within the Pretoria Group: the Bushy Bend Lava member at the top of the Rooihoogte Formation, and the Hekpoort Formation above the Boshoek and Timeball Hill Formations.

The Bushy Bend Lavas are amygdaloidal lavas that occur on top of the Rooihoogte Formation and below the Timeball Hill Formation of the Pretoria Group (Eriksson et al., 1994; Coetzee, 2001). These represent isolated occurrences in the southwest of the Transvaal Basin and have been described from Potchefstroom, where thicknesses of up to $90 \mathrm{~m}$ are reached (Lenhardt et al., 2012), from Gopane and eastern Botswana (Eriksson et al., 1994), and from Pretoria, where they occur as thin and highly altered basalts (Van der Neut, 1990). It is suggested that these lavas were extruded subaerially (Eriksson et al., 1994) from basalt-andesite fissure vents (Coetzee, 2001) of the relatively restricted Bushy Bend lavas in the south of the Transvaal Basin. According to Coetzee (2001), these lavas occur mainly from Potchefstroom to Ventersdorp and as far west as Botswana, which includes the Lichtenburg area. The close spatial and chronological association of the Rooihoogte Formation with these isolated occurrences of the Bushy Bend lavas suggests that the unabraded chalcedony and carnelian from some of the Lichtenburg karst holes have been weathered out of local and small fissure eruption of this volcanic member rather than from Karoo volcanics on the Springbok Flats as has previously been 
EARLY PERMIAN DIAMOND-BEARING PROXIMAL ESKERS IN THE LICHTENBURG/VENTERSDORP AREA OF THE NORTH WEST PROVINCE, SOUTH AFRICA

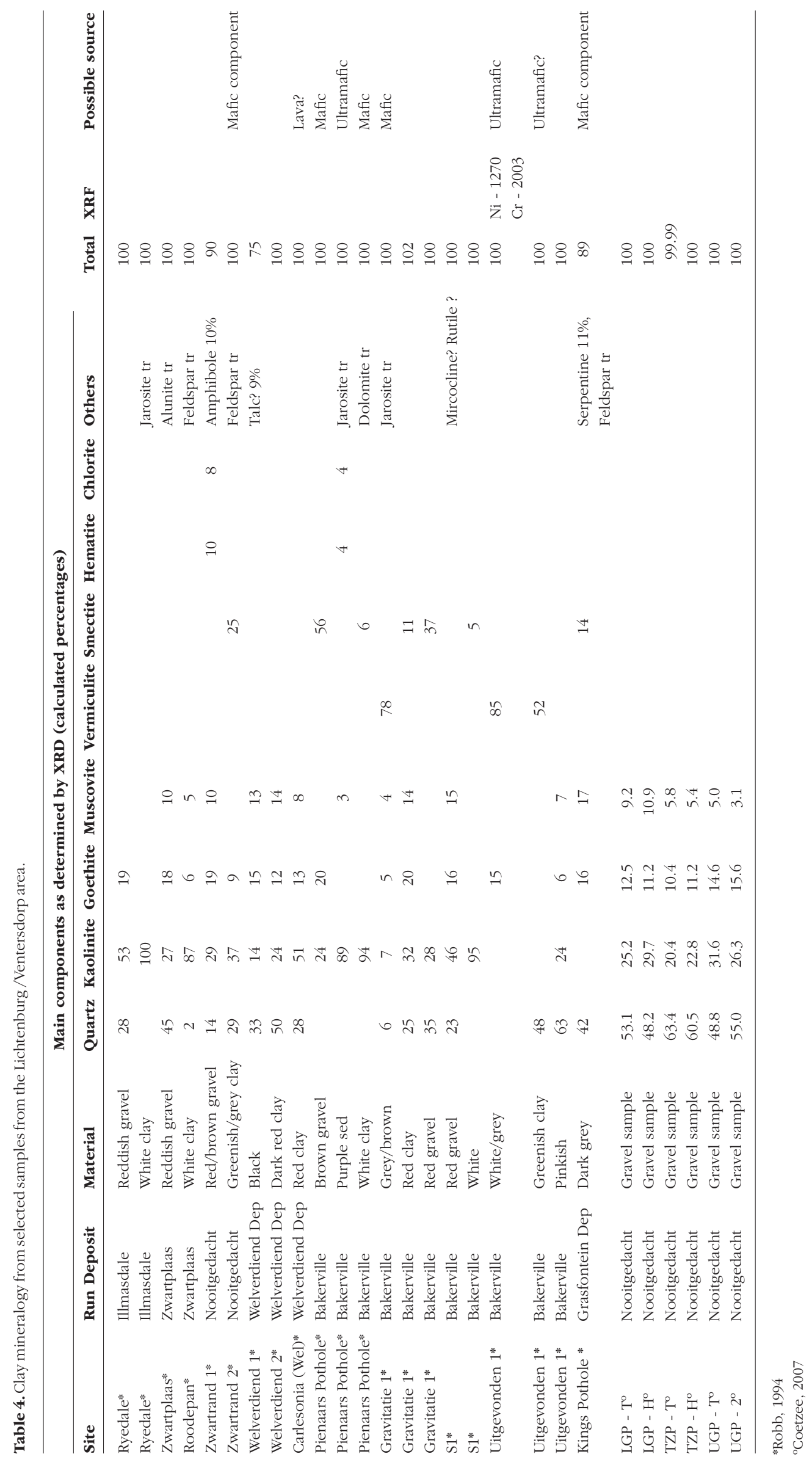




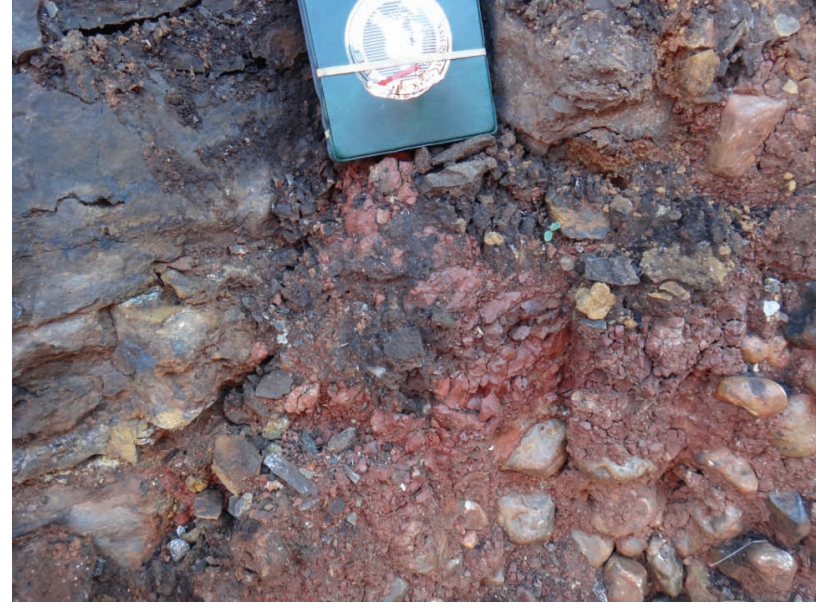

Figure 14. Red clay 'plastered' against weathered dolomite bedrock (Wad), and preserved as thin remnants of weathered basalt in the Van Wyks fissure fill on the Bakerville run. Analyses from similar red clay samples suggest a mafic or ultramafic source rock. Notebook for scale.

suggested (Harger, 1928; Williams, 1932; Du Toit, 1951). Finally, several clay samples from Lichtenburg indicate that these were derived from rocks with mafic (Kings and Pienaars potholes) and ultramafic (Uitgevonden) composition (Table 4), suggesting that these were decomposed remnants of a local Bushy Bend equivalent.

The likely source for the highly abraded and pale coloured agates is Hekpoort Formation basaltic andesitic lavas, which occurs in the southcentral part of the Transvaal Basin. This unit can be up to $1,100 \mathrm{~m}$ thick and thins to the north, with single flows of up to $60 \mathrm{~m}$ thick varying from massive to amygdaloidal, (Lenhardt et al., 2012). In the North West Province these occur between 50 and $100 \mathrm{~km}$ to the north and northeast of the Lichtenburg/Ventersdorp area stretching from Zeerust to Magaliesburg.

\section{Diamonds and zircons}

Sinclair (1940) and Du Toit (1951) noted that the diamonds in the Lichtenburg area are of much lower average value than those from Ventersdorp, which is confirmed by Marshall (1985), who compiled all the diamond records from 1904 to 1984 on a farm by farm basis and is reported here per run (Table 2). The Welverdiend deposit and the Vlakplaats run reported the lowest values. The values for Mahikeng are distorted as these are based on recoveries between 1986 and 1992. In addition, the Lichtenburg field produced well-formed crystals of less than $0.5 \mathrm{ct} / \mathrm{st}$, many fragments, a relatively high percentage boart and poor quality stones, and very few large diamonds (Du Toit, 1951). In fact the largest diamonds on record are a $101.25 \mathrm{ct}$ stone (Bakerville run), a $94 \mathrm{ct}$ stone (Vlakpaats run) and a $99 \mathrm{ct}$ stone (Twee Buffels run) (Du Toit, 1935, 1951). Many of the stones in Lichtenburg are spotted, and yellow and brown in colour, and diamonds with a greenish tint were found over a limited area on Grasfontein 356 JP (Du Toit, 1951). The diamonds from the Mooi River valley, south of Ventersdorp, were mostly light Cape to yellow (Du Toit, 1935).
Detailed studies of surface features of diamonds from the North West Province show that those from north of Ventersdorp (Klipgat and Nooitgedacht) are similar in terms of green spots, low level of colourless stones and a higher proportion of brown and deformed diamonds, a relatively high level of terracing and zigzag features and generally a low level of fine frosting, and are different to those from Lichtenburg and Holfontein, respectively (Robinson, 2004; Van der Westhuizen, 2012).

The main observation from a parcel of 166 diamonds (Table 5) from Van Wyks/MSG pothole (Grasfontein 356JP), is that more than $50 \%$ of the diamonds are classified as boart, many of the stones are fragile and cracked and there is no evidence of transportation, except for three stones that could probably be detrital (Robinson, 2004). A local proximal source is therefore envisaged. This is supported by an abundance of, mainly unabraded, kimberlitic indicators minerals from this site. The absence of maccles, which are often seen in the Lichtenburg/Ventersdorp area (Robinson pers. comm., 2004), also argues for a local source.

Two diamonds from this parcel contained clinopyroxene inclusions (Figure 15). Two pale-green clinopyroxene inclusions from the larger colourless diamond were recovered by J. Harris (Glasgow University) and sent to D. Phillips (University of Melbourne) for $\mathrm{Ar}^{40} / \mathrm{Ar}^{39}$ step-heating experiments. The low temperature steps give older ages than the fusion steps, which means that inherited argon is present. The results for both inclusions were indistinguishable and indicate an emplacement age of between 500 and $600 \mathrm{Ma}$ (D. Phillips pers. comm., 2013). Older intrusion ages such as for Premier are definitely ruled out, and the possibility that the diamonds have been derived from Cretaceous/ Jurassic kimberlites is unlikely (D. Phillips, pers. comm., 2013).

In addition, low-U zircons, likely mantle derived, were obtained from concentrate from diamond workings at Pienaars

Table 5. Diamond recovered from Van Wyks/MSG pothole on Grasfontein 356JP, classified by group (after Robinson, 2004).

\begin{tabular}{|c|c|c|c|}
\hline Group & $\mathbf{N}$ & $\%$ & Comment \\
\hline Light coloured & 35 & 21.1 & $\begin{array}{l}\text { Nearly colourlesss; mostly } \\
\text { dodecahedral; T/L/ZZ common. }\end{array}$ \\
\hline Boart & 85 & 51.2 & $\begin{array}{l}\text { Only } 19 \text { stones examined; } \\
\text { Inclusions presumed graphite; } \\
\text { Mostly rounded dodecahedral, } \\
\text { usually broken. }\end{array}$ \\
\hline Brown & 17 & 10.2 & $\begin{array}{l}\text { Large dodecahedral mostly } \\
\text { broken; T/L common; } 2 \text { are } \\
\text { fragile. }\end{array}$ \\
\hline Dark brown & 18 & 10.8 & $\begin{array}{l}\text { Mainly broken rounded } \\
\text { dodecahedral; T/L common. }\end{array}$ \\
\hline Mauve & 1 & 0.6 & $\begin{array}{l}\text { Broken dodecahredal: } \\
\text { L common. }\end{array}$ \\
\hline Aggregate & 2 & 1.2 & $\begin{array}{l}\text { Light coloured dodecahedral } \\
\text { aggregates: } 1 \text { with ZZ pattern. }\end{array}$ \\
\hline Yellow & 8 & 4.8 & $\begin{array}{l}\text { Deep yellow broken } \\
\text { dodecahedral; T/L/ZZ common. }\end{array}$ \\
\hline Total & 166 & 99.9 & \\
\hline
\end{tabular}

NB: Classification by Robinson (2004).

$\mathrm{T}=$ Terracing, $\mathrm{L}=$ Lamination lines, $\mathrm{ZZ}=$ Zigzag pattern 
pothole, and gave an age range between 489 and $664 \mathrm{Ma}$ (De Wit et al., 1998). This supports the inference of local late Neoproterozoic to Cambrian kimberlite source(s) similar in age to some important diamond-bearing kimberlites elsewhere in southern Africa (Jelsma et al., 2009).

Detrital crustal zircons were recovered from Karoo sandstone samples from the Welverdiend (35) and Pienaars 'potholes' (42). The samples were analysed using a LA-ICP-MS at the De Beers Laboratories in Crown Mines (Van der Linde, 2015). The following $(<10 \%$ discordance) age groups were obtained: $3148 \pm 140,2824 \pm 51,2067 \pm 53$ and $1046 \pm 30 \mathrm{Ma}$ (Welverdiend), and $3144 \pm 58,2044 \pm 21$ with a single grain at 2,809 $\pm 98 \mathrm{Ma}$ (Pienaars pothole) (Van der Linde, 2015). The youngest ages are Kibaran, and others are Bushveld and Archaean ages, so no 'young' crustal zircons have been recovered from Lichtenburg.

\section{Depositional model}

The glacial pavements on roches mountounées, percussion scars and polished surfaces, and Lower Karoo remnants indicate that the dolomite surface on which the gravels were deposited was scoured by glacial activity. The relatively flat and sometimes uphill sections of the gravel runs on an almost flat pre-Karoo surface is not possible in a normal fluvial environment. If these gravels are remnants of subterranean rivers, then substantial lowering of the dolomite surface would have to be envisaged to expose these, and there is little evidence or such lowering. Furthermore, syenite and dolerite dykes have effectively compartmentalised the groundwater regime in the dolomites, forming barriers to ground-water movement (De Bruyn and Bell, 2001) and restricting the development of large subterranean rivers.

Uphill flow has only been described under ice, and as long as the surface slope of the glaciers decreases in a downflow direction, subglacial channels can flow 'uphill' against a reverse bedslope (Van der Veen, 2013). The coarse bedload containing rounded and scarred boulders accentuate the high energy levels operating during transport on this flat surface. This can only be

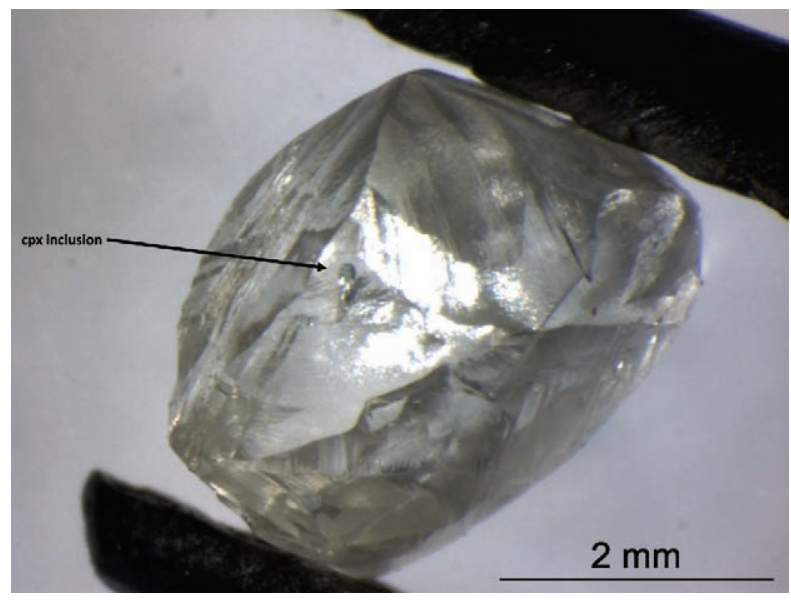

Figure 15. Diamond from MSG (Van Wyks fissure fill on the Bakerville run) with clinopyroxene inclusion used for Ar/Ar dating pointed out by arrow (photoI. Chinn). generated in subglacial conditions, which ignores topography, where clasts up to boulder size are subjected to inter-particle collisions, rounding and polishing, in high-pressure subglacial channels. Polished surfaces are generally associated with meltwater erosion, sub-glacial slurry or saturated till (Sharp, 1989).

These runs have therefore been interpreted as iceflows that developed during the last melting stages of the Cargonian ice cap, or Visser's (1997) cycle 4 (early Permian) of the Dwyka deglaciation, and in close proximity to the centre of this ice cap. Diamonds derived from Cambrian kimberlites and the absence of crustal zircons younger than 1,000 Ma support the time frame in which these gravels were deposited.

The most common lithofacies found in the gravels are matrix- and clast- supported diamictites (Dmm and Dcm) these are dominated by clasts of local bedrock and deposited as clayey gravel in sub-glacial tunnels proximal to the ice centre, much like in Estonia where the proximal parts of the eskers are composed of coarse unstratified poorly-sorted sediment (Karukäpp, 2005). In the Lichtenburg area, the runs would resemble R-channels (Boulton et al., 2009), which are flow-parallel streams in subglacial tunnels that arch up into the ice, leaving behind positive ridges once the ice has melted. In the Ventersdorp area there is more evidence of incision, particular along zones of structural weakness while segmented runs formed by pulsed glacier retreat. The tunnels have the capacity to discharge efficiently large meltwater fluxes (Boulton et al., 2009) and the clay-rich units are indications of periodical changes in subglacial rapidly changing water discharges and flow rates. Diamictite facies with some internal structure, either graded or stratified (Dmg or Dmc), are more common in the central region. The gavel facies $\mathrm{Gm} / \mathrm{Gp}$ exposed at the Tirisano mine on the Nooigedacht run, resembling the UGP unit (Marshall and Norton, 2009), overly the basal Dmm and Dcm units. These gravel facies are generally flatlying or gently dipping to the south and were likely deposited by subglacial streams, bringing large volumes of water and sediments released during the melting of the ice. This occurred in a subaqueous deltaic or fan-head environment at the margin of the ice sheet during its retreat. This unit was relatively flat and spilled over the edges of the depression of the main pit (Marshall and Norton, 2012).

The shattered and fractured bedrock (BBcsh) commonly associated with the bedrock breccias (BBm) are interpreted as frost shattering (Figure 7a). The frost action is supported by several ice wedges found on some of the Dmm facies in the Manana run, for instance. One of these is some $40 \mathrm{~cm}$ deep and $15 \mathrm{~cm}$ wide on top, and infilled with finer grained sandy material from the overlying Dcg facies. The BBm facies is interpreted as the transition from brittle shearing at the ice-bed interface to ductile deformation as diamictite thickness increases (Figure 7b). The folded bedrock breccia $(\mathrm{BB}(\mathrm{t}))$, composed mainly of chert grading into the $\mathrm{Dmm} / \mathrm{Dcm}$ facies resembles glacitectonic brecciation (Figure 7c). Similar facies have been described by Visser (1987) from a borehole near Winburg on a pre-Karoo high, with brecciated and glaciotectonised bedrock at the base and cavities filled with Dwyka diamictite, which was probably injected under pressure by the ice. The breccia grades upwards 
into a poorly sorted conglomerate, much like the sections described above in the North West Province.

Even on relatively flat surfaces water velocities in these type of ice tunnels lie in a narrow range of around 2 to $6 \mathrm{~m} / \mathrm{s}$ (Boulton et al., 2009) and the presence of the transported oversize material with its percussion damaged surfaces in the Dmm/Dcm gravels of some of the runs support such high flow regimes. The scarred large clasts are present in most runs but are particularly common in the Twee Buffels and Schilpadverdriet runs. Boulton et al. (2009) further showed that the spacing between eskers on such flat surfaces is typically between 8 and $25 \mathrm{~km}$, depending on the transmissivity. The average spacing of the runs on the prePretoria surface $13.6 \mathrm{~km}$, which is also very similar to the spacing of eskers in northern Estonia where eskers have very similar morphologies and distribution patterns to the gravel runs of the North West Province (Rattas, 2007). Eskers are the infillings of ice-walled steam channels and may record deposition in subglacial, englacial or supraglacial drainage networks. The main precondition of esker formation, even in a proximal setting, is considered to be the rigid non-permeable subglacial surface (Boulton, et al., 1996; 2003). In northern Estonia and in the North West Province, for instance, eskers have developed preferentially on the less permeable Ordovician/Silurian and Proterozoic carbonates, respectively, where the meltwater flows through channels or conduits in tunnel valleys and forms channel fills like eskers that are sub-parallel to the ice-stream reflecting meltwater to the ice margin (Rattas, 2005). In the North West Province, eskers of proximal origin are preserved on the relatively flat dolomite surface and are absent to the south and below the dolomite edge due to the rapidly steepening slope into the Ecca basin. These proximal eskers are more common in the Lichtenburg area, while the tunnel conduits in the Ventersdorp area are more incised into the bedrock. For both, however, there is a good correlation between the location of these features, linear structures and karst phenomena, commonly observed in area with sedimentary bedrock (Karukäpp, 2005). Locally, the more incised runs seem to have a direct association with structures, while the karstification processes have been ongoing in pre-, syn- and post-deposition times.

Visser (1987b) defines the upland facies association consisting either of reworked glacial debris, locally derived breccia or both. These facies have been described in borehole cores near Winburg, which occurs on a pre-Karoo high. Here, brecciated and glaciotectonized bedrock has cavities filled with diamictite or pebbly sandstone and conglomerate. The diamictite has been interpreted as a slurry injected under pressure by the ice into the cavities, whereas channelised sediments were washed in by subglacial and post glacial streams. The breccia commonly grades into moderately sorted conglomerate that consists of angular to sub-rounded fragments, with compositions similar to that of the underlying bedrock (Visser, 1987b).

Visser $(1987,1997)$ suggested that the Cargonian highland maintained a small ice cap well into the Permian and since these eskers represent the final stages of the Dwyka deglaciation, an early Permian age is advocated. The main southwesterly ice stream would have come through the gap at Makaalstad, west of Koster, fanning out to the southwest, south and southeast, over the dolomites as proximal eskers on brecciated and reworked bedrock,

\section{Conclusions}

In summary, it is suggested that a gently dipping dolomite surface was scoured during Dwyka times by an ice cap, and that at least two major valley glaciers (valleys now occupied by the Mooi and Harts Rivers), and numerous smaller valley glaciers, fed into the main Karoo Basin to the south and west. This surface, on which the Dwyka gravel runs were subsequently deposited, was initially shaped over a period of at least $80 \mathrm{Myr}$ in prePretoria Group times, and thereafter episodically re-exhumed possibly from post-Waterberg to Pre-Karoo times; during Dwyka times; and again during the Mesozoic and Cainozoic. It contains remnants of pre-Pretoria karst sediments, Dwyka glacial markings and deposits, remnants of isolated Karoo sequences, and evidence of the Cretaceous African landsurface and younger Cainozoic erosion cycles. It is therefore a relatively thin surface 'layer', or a significant 'palimpsest', that represents a long history of deposition, erosion and non-deposition, locally preserved as condensed sequences, of which the proximal eskers are small parts.

The gravel 'runs' around Lichtenburg and Ventersdorp are remnants of sub-glacial deposits preserved on this old erosional land surface as diamictites deposited within southward flowing sub-glacial tunnels or proximal eskers during the final stages of the Gondwana-wide Dwyka glaciation in the early Permian. Analyses of inclusions in diamond and zircons support this time frame, and the fact that the agate populations most likely relate to the Pretoria Group and not to the Karoo volcanics adds further weight to the diamictites being of Dwyka age.

There are at least two population of diamonds: proximal source(s) north of Lichtenburg and more distally derived population(s) in the Ventersdorp district, with diamonds that have different surface features. Detailed analysis of these Dwyka aged gravels is required to establish the location of these sources.

\section{Acknowledgements}

The author wishes to acknowledge De Beers Exploration for the zircon analysis, Jeff Harris and Dave Phillips for the diamond inclusion data, Edgar Stettler for Lichtenburg drilling data, Rockwell Diamonds for providing the clay analysis, Tania Marshall for generously providing photos and unpublished reports, McDonald Kahari for helping with the topographical image, and John Ward and Maarten de Wit for discussions and suggestions on the 'western Transvaal'. Tania Marshall, Andy Moore and an anonymous reviewer are thanked for their constructive comments and suggestions, and Lewis Ashwal for the final edit.

\section{References}

Anderson, J.M., 1977. The Biostratigraphy of the Permian and Triassic, Part 3: A review of Gondwana Permian palynology with particular reference to the northern Karoo Basin, South Africa. Memoirs of the Botanical Survey of South Africa, 41, 188pp. 
Appleyard, C.M., 2006. U-Pb dating of detrital zircons from alluvial sample PAN270, South Africa. De Beers Group Exploration, unpublished report for Barker Mining and Metal, RSA 05/0910, 5pp.

Beukes, N.J., van Niekerk, H.S. and Gutzmer J., 1999. Post Gondwana land surface and pedogenetic ferromanganese deposits on the Witwatersrand at the West Wits Gold Mine, South Africa. South African Journal of Geology, $102(1), 65-82$

Bordy, E.M., Segwabe, T. and Makuke B., 2010. Sedimentology of the Upper Triassic - Lower Jurassic (?) Mosolotsane Formation (Karoo Supergroup), Kalahari Karoo Basin, Botswana. Journal of African Earth Sciences, 58 , 127-140.

Boulton, G.S., Magdorn, M., Maillot, P.B. and Zatsepin, S., 2009. Drainage beneath ice sheets: groundwater-channel coupling and the origin of esker systems from former ice sheets. Quaternary Science Reviews, 28, 621-638.

Boulton, G.S., Vidstrand, P., Maillot, B. and Zatsepin, S., 2003. Theory of drainage beneath ice sheets and the origin of esker and tunnel valley systems from the last European ice sheet. INQUA XVI International Congress, Reno, Nevada, USA, Programs with Abstracts, 124.

Bredell, J.H., 1978. Prospecting for refractory clays on the East Rand. Geological Survey of South Africa, Bulletin, 62, 20pp.

Brink, A.B.A. and Partridge T.C., 1965. Transvaal karst: some considerations of development and morphology, with special reference to sinkholes and subsidence on the Far West Rand. South African Geographical Journal, 47, 11-34.

Brown, R.W., Summerfield, M.A. and Gleadow, A.J., 1994. Apatite fission track analysis: its potential for estimation of denudation rates and implications for models of long-term landscape development. Process models and theoretical Geomorphology, 2453.

Brown, R.W., Summerfield, M.A. and Gleadow, A.J.W., 2002. Denudational history along a transect across the Drakensberg Escarpment of southern Africa derived from apatite fission track thermochronology. Journal of Geophysical Research, 107 (B120, 2350)

Bühmann, C. and Bühmann, D., 1990. Clay minerals as palaeoenvironment indicators exemplified on a Karoo sequence from the Bothaville area, South Africa. South African Journal of Geology, 93(3), 505-513.

Bumby, A.J., Eriksson, P.G., Catuneanu, O., Nelson, D.R. and Rigby, M.J., 2012. Meso-Archaean and Palaeo-Proterozoic sedimentary sequence stratigraphy of the Kaapvaal Craton. Marine and Petroleum Geology, 33, 92-116.

Burke, K., 1996. The African Plate. South African Journal of Geology, 99, 399-409.

Coetzee, L.L., 2001. Genetic stratigraphy of the Paleoproterozoic Pretoria Group in the Western Transvaal. Unpublished MSc thesis, University of Johannesburg, 212pp.

Cooks, J., 1968. Paleodreineringslyne in die Wes-Transvaalse karstgebied. South African Geographical Journal, 50, 101-109.

Cousins, C.A., 1950. Sub-Karroo contours and notes on the Karroo Succession in the Odendaalsrus area of the Orange Free State. Transactions of the Geological Society of South Africa, 53, 229-241.

Davies, G. and Prevost, X.M., 1978. The geology and mineral resources of an area around Lichtenburg. Report of the Geological Survey of South Africa, 1978-0137, 64pp.

De Bruyn, I. A. and Bell, F.G., 2001. The Occurrence of Sinkholes and Subsidence Depressions in the Far West Rand and Gauteng Province, South Africa, and Their Engineering Implications. Environmental and Engineering Geoscience, VII (3), 281-295.

De Wit, M.C.J., 1981. Geophysical investigation and geological interpretation of part of the diamondiferous gravels on the Grasfontein farm (356 JP), west of Bakerville. Unpublished MSc thesis, University of Pretoria, South Africa, 93pp.

De Wit, M.C.J., Morelli, C. and Skinner, C.P.S., 1998. A reinterpretation of the Lichtenburg diamond deposits. Extended abstracts of the 7 th International Kimberlite conference, Cape Town, South Africa, 195.

De Wit, M.C.J., Marshall, T.R. and Partridge T.C., 2000. Fluvial deposits and drainage evolution. In, T.C. Partridge and R.R. Maud (Editors), The Cenozoic of Southern Africa, Oxford Press, 55-72.

Draper, D., 1927. On the occurrence of diamonds associated with Chert beds of the dolomite series in the District of Ventersdorp and Lichtenburg, Transactions of the Geological society of South Africa, 30, 69-88

Du Toit, A.L., 1910. The evolution of the river system of Griqualand-West. Transactions of the Royal Society of South Africa, 1, 347-361.

Du Toit, A.L., 1933. Crustal movement as a factor in the geographical evolution of South Africa. The South African Geographical Journal, XVI, 2-20.

Du Toit, A.L., 1935. The Diamondiferous alluvials. Explanation for sheet 53, Geological Survey of South Africa, Pretoria, Chapter X, 49-64

Du Toit, A.L., 1951. Diamondiferous gravels of Lichtenburg. Geological Survey of South Africa, Memoire, 44, 58pp.

Eggleton, R.A., Foudoulis, C and Varkevisser, D., 1987. Weathering of basalt: changes in rock chemistry and mineralogy. Clay and Clay minerals, 35 (3), 161-169.

Eriksson, P.G., 1988. Sedimentology of the Rooihoogte Formation, Transvaal Sequence. South African Journal of Geology, 91 (4), 477-489.

Eriksson, P.G., Engelbrecht, J.P., Res, M. and Harmer, R.E., 1994. The Bushy Bend Lavas, a new volcanic member of the Pretoria Group, Transvaal Sequence. South African Journal of Geology, 97 (1), 1-7.

Eriksson, P.G., Altermann, W. and Hartzer, F.J., 2006. The Transvaal Supergroup and its precursors. In: M.R. Johnson, C.R. Anhaeusser, R.J. Thomas (Editors). The Geology of South Africa, Geological Society of South Africa, Council for Geoscience, 237-260.

Eriksson, P.G., Altermann, W., Catuneanu, O., Van der Merwe, R. and Bumby, A.J., 2001. Major influences on the evolution of the 2.67 to $2.1 \mathrm{Ga}$ Transvaal Basin. Sedimentary Geology, 141-142, 205-231

Eyles, N., Eyles, C.H. and Miall, A.D., 1983. Lithofacies types and vertical profile models; an alternative approach to the description and environmental interpretation of glacial diamict and diamictite sequences. Sedimentology, 30, 393-410.

Folk, R.L., 1968. Petrology of sedimentary rocks. The University of Texas, Geology, 140pp.

Green, P.F., 1986. On the thermos-tectonic evolution of Northern England: evidence from fission track analysis. Geological Magazine, 123, 493-506.

Green P., Swart, R., Jacob, J., Ward, J. and Bluck, B., 2009. Thermochronology and landscape development in southern Africa. PESGB HGS, Africa meeting, Extended abstracts, $7 \mathrm{pp}$.

Harger, H.S., 1928. Discussion of Draper's paper 'On the Association of Diamonds with the Chert Bed of the Districts of Ventersdorp and Lichtenburg'. Proceedings of the Geological Society of South Africa, 30, 39-44 (originally XXX, xxxix-xliv).

Isbell, J.L., Cole, D.I. and Catuneanu, O., 2008. Carboniferous-Permian glaciation in the main Karoo Basin, South Africa: Stratigraphy, depositional controls and glacial dynamics. In: C.R. Fielding, T.D. Frank and J.L. Isbell (Editors). Resolving the Late Paleozoic Ice age in time and Space. Geological Society America, Special Paper, 441, 71-82.

Jaspen, P., Bonow, J.M., Green, P.F., Chalmers, J.A. and Lidmar-Bergström, K. 2006. Elevated passive continental margins: long-term highs or Neogene uplifts? New evidence from West Greenland. Earth Planetary Science letters, 248(1), 330-339

Jelsma, H., Barnett, W., Richards, S. and Lister, G., 2009. Tectonic setting of kimberlites. Lithos 112S, 155-165.

Karukäpp, R., 2005. Eskers in the periphery of their distribution in North Estonia. Proceedings of the Estonian Academy of Sciences, Geology, 54 (1), 26-39.

Klama, K.O., 2008. U-Pb Geochronologie, Hf isotopie und Spurenelementgeochemie detritischer Zirkone aus rezenten sedimenten des Orange-und Vaal River Flusssystems in Südafrika. PhD (unpubl.), University of Frankfurt am Main, 179pp.

Lenhardt, N., Eriksson, P.G., Catuneanu, O. and Bumby, A.J., 2012. Nature of and controls on volcanism in the c. 2.32 to 2.06 Ga Pretoria Group, Transvaal Supergroup, Kaapvaal Craton, South Africa. Precambian Research, 212-215, 106-123

Leveson, D.J., 2002. The concept of gradient. Cuny College Brooklyn courses. Lynn, M.D., 2014. Lichtenburg Project, Site Visit Report. The MSA Group (Pty) Ltd report on behalf of: The Gold Company (Pty) Ltd, J2903, 12pp.

Mackintosh, V., 2013. The application of apatite (U-Th)/He thermochronology to constraining the cooling, erosion and uplift history of southern Africa. Internal report, School of Geographical and Earth Sciences University of Glasgow, $5 \mathrm{pp}$

Mapeo, R.B.M., Armstrong, R.A., Kampunzu, A.B., Modisi, M.P., Ramokate, L.V and Modie, B.N.J., 2006. A ca. 200 Ma hiatus between the lower and Upper Transvaal Groups of southern Africa: SHRIMP U-Pb detrital zircon evidence for the Segwagwa Group, Botswana: Implications for Palaeoproterozoic glaciations. Earth and Planetary Science Letters, 244, 113-132.

Maree, B.D., 1987. Die afsetting en verspreiding van spoel diamante in SuidAfrika. South African Journal of Geology, 90 (4), 428-447. 
Maree, B.D., 1988. Bespreking van 'Die afsetting en verspreiding van spoel diamante in Suid Afrika'. South African Journal of Geology, 91 (3), 420-424.

Marshall, T.R., 1987. Alluvial diamond occurrences of the western and south western Transvaal - a compilation of production data. Economic Research Unit, University of the Witwatersrand, Johannesburg, Information Circular, no. 194

Marshall, T.R., 1989. The alluvial diamond fields of the western Transvaal, South Africa: Origin of diamonds and gravels. In: J. Ross (Editor). Kimberlites and related rocks, Vol. 2, Geological Society of Australia, Special Publication, 14, 1204-1214

Marshall, T.R., 1990. The nature, origin and evolution of the diamondiferous gravels of the southwestern Transvaal. Unpublished $\mathrm{PhD}$ thesis, University of the Witwatersrand, Johannesburg, South Africa, 211pp.

Marshall, T.R. and Norton, G.A., 2009. The nature of the alluvial diamond deposits of the Ventersdorp district, north West Province, South Africa. South African Journal of Geology, 112, 109-124.

Marshall, T.R., and Norton, G.A., 2010. Revised technical report on the Tirisano Alluvial Diamond project, Ventersdorp District, South Africa, for Rockwell Diamonds INC, 160pp.

Marshall, T.R., and Norton, G.A., 2012. Report on the Tirisano Alluvial Diamond project, Ventersdorp District, South Africa, for Rockwell Diamonds INC, 113pp.

Martini, J. and Kavalieris, I., 1976. The Karst of the Transvaal (South Africa). International Journal of Speleology, 8, 229-251.

Mayer, J.J., 1973. Morphotectonic development of the Harts River Valley in relation to the Griqualand-Transvaal axis and the Vaal and Molopo rivers. Transactions of the Geological Society of South Africa, 73, 183-194.

Mayer, J.J., 1985. Interpretation of heavy-mineral patterns in sandy soils of the region drained by the upper reaches of the Harts River. Transactions of the Geological Society of South Africa, 88, 27-32.

Miall, A.D., 1978. Lithofacies types and vertical profile models in braided streams; a summary. In: Fluvial Sedimentology, A.D.Miall (Editor). Memoire Can. Society of Petroleum Geologists, 5, 597-604

Nel, T.L., Frommurze, H.F., Willemse, J. and Haughton, S.H., 1935. The Geology of Ventersdorp and adjoining country. Explanation of Sheet 543 (Ventersdorp). Geological Survey of South Africa, Government PrintersS.6869-1,500

Pack, A., Gutzmer J., Beukes, N.J. and van Niekerk, H.S., 2000. Supergene Ferromanganese Wad deposits derived from Permian Karoo Strata along the Late Cretaceous-Mid-Tertiary African Land Surface, Ryedale, South Africa. Economic Geology, 95, 203-220.

Partridge, T.C. and Maun, R.R., 1987. Geomorphic evolution of southern Africa since the Mesozoic. South African Journal of Geology, 90, 179-208.

Partridge, T.C., 1998. Of diamonds, dinosaurs and diastrophism: 150 million years of landscape evolution in southern Africa. South African Journal of Geology, 101, 167-184

Rattas, M., 2005. Subglacial drainage system under an East-Baltic Weichselian ice stream: distribution of eskers and tunnel valleys in Estonia. In: V. Kolka and O. Korsakova, (Editors). Quaternary geology and landforming processes, proceedings of the International field symposium, Kola Peninsula, NW Russia. Apatity: Kola Science centre RAS, 52-54.

Rattas, M., 2007. Spatial distribution and morphological aspects of eskers and bedrock valleys in north Estonia: implications for the reconstruction of a subglacial drainage system under the late Weichselian Baltic ice stream. In: P. Johansson and P. Sarala (Editors). Applied Quaternary research in the central part of glaciated terrain, Geological Survey of Finland, Special Paper, 46, 63-68.

Retief, E.A., 1960. The diamondiferous gravels in the Lichtenburg-Ventersdorp area. Report of the Geological Survey of South Africa, 1960-0004, 68pp.

Robb, V.M., 1994. Clay analysis of twenty one samples for the Western Transvaal clay project. Anglo American Research Laboratory (Pty) Ltd, Report M94/0489, 7pp.

Robinson, D.N., 2004. The characteristics of diamonds, also studies by infrared absorption from 'Mike-se Gat', adjacent to Van Wyks Pothole, Lichtenburg, Internal report for Synodinos, $8 \mathrm{pp}$

Sharp, R.H. and Shaw, J., 1989. Erosion of bedrock by subglacial meltwater. Geological Society of America Bulletin, 101 (8), 1011-1020.

Sinclair, W.E., 1940. Alluvial diamonds in South Africa: a retrospective account of the Lichtenburg Diggings, one of the world's big alluvial diamond fields. Mining Magazine, 62 (4), 213-219.

Smith, R.A., 1984. The Lithostratigraphy of the Karoo Supergroup in Botswana.
Geological survey of Botswana, Bulletin, vol. 26, 239pp.

Stanley, R.S., Flowers, R.M. and Bell, D.R., 2013. Kimberlite (U-th)/He dating links surface erosion with lithospheric heating, thinning, and metasomatism in the southern African plateau. Geology, 41 (12), 1243-1246.

Stettler, E.H., 1979. A geological and geophysical investigation of the diamond runs on Ruigtelaagte and vicinity, in the Bakerville area, Lichtenburg District. Unpublished MSc thesis, University of Pretoria, South Africa, 112pp.

Stratten, T., 1979. The origin of the diamondiferous alluvial gravels in the southwestern Transvaal. In: A.M. Anderson and W.J. von Biljon (Editors) Some sedimentary basins and associated ore deposits of South Africa. Special Publication of the Geological Society of South Africa, 6, 219-228.

Tinker, J., de Wit, M.J. and Brown, R., 2008. Linking source to sink: Evaluating the balance between onshore erosion and offshore sediment accumulation since Gondwana break-up, South Africa. Tectonophysics, 455, 94-103.

Van der Linde, G., 2015. U-Pb ages of detrital zircons from EIA662 and EIA664 (RSA140026). De Beers Group Services, report 157790, 12pp.

Van der Neut, M., 1990. Afsettingstoestande van die Pretoria Groep gesteentes in die Pretoria-Bronkhorstspruit-Delmas gebied. Unpublished MSc thesis, University of Pretoria.

Van der Veen, C.J., 2013. Fundamentals of Glacier dynamics. 2nd Edition, CRC Press, 363pp

Van der Westhuizen, A., 2012. Provenance of alluvial diamonds in southern Africa: a morphological and mineral chemistry study of diamonds and related heavy minerals from the Vaal-Orange system and the West Coast. D.Phil. thesis (unpubl), University of Stellenbosch, 394pp.

Van Niekerk, H.S., Beukes, N.J. and Gutzmer, J., 1999b. Post-Gondwana pedogenic ferromanganese deposits, ancient soil profiles, African land surfaces and palaeoclimatic change on the Highveld of South Africa. Journal of African Earth Sciences, 29 (4), 761-781.

Van Niekerk, H.S., Gutzmer, J., Beukes, N.J., Phillips, D. and Kiviets, G.B., 1999b. $\mathrm{An}^{40} \mathrm{Ar}^{39} \mathrm{Ar}$ age of supergene K-Mn oxyhydroxides in a postGondwana soil profile on the Highveld of South Africa. South African Journal of Science, 95, 450-455.

Visser, J.N.J. and Kingsley, C.S., 1982. Upper Carboniferous glacial valley sedimentation in the Karoo Basin, Orange Free State. Transactions of the Geological Society of South Africa, 85, 71-79

Visser, J.N.J., 1987a. The palaeogeography of part of southwestern Gondwana during the Permo-Carboniferous glaciation. Palaeogeography, Paleoclimatology, Palaeoecology, 61, 205-219.

Visser, J.N.J., 1987b. The influence of topography on the Permo-Carboniferous glaciation in the Karoo Basin and adjoining areas, southern Africa. In: D.H. Elliot, J.W. Collison, G.D. McKenzie and S.M. Haban (Editors), Gondwana Six: Stratigraphy, Sedimentology and Paleontology, 41, 123-129.

Visser, J.N.J., 1997. Deglaciation sequences in the Permo-Carboniferous Karoo and Kalahari basins of southern Africa: a tool in the analysis of cyclic glaciomarine basin fills. Sedimentology, 44, 507-521.

Von Backström, J.W., Schumann, F.W., Le Roex, H.D., Kent, L.E. and du Toit, A.L., 1953. The geology of the area around Lichtenburg. Geological Survey of the Union of South Africa.

Von Gottberg, B., 1970. The occurrence of Dwyka rocks and glacial topography in the South-western Transvaal, 73, 99-106.

Ward, J.D., Bluck, B.J., Swart, R., Jacob, R.J., de Wit, M.C.J. and Spaggiari, R.I., 2014. Concave polished rock patches: pointers to widespread pre-Karoo landscape remnants in southern Africa. Abstract Roy Miller Symposium Celebrating 50 years of Geological Service to Namibia.

Wellington, J.H., 1929. The Vaal Limpopo watershed. The South African Geographical Journal, XII, 36-45.

Wildman, M., Beucher, R., Brown, R., Persano, C. and Stuart, F., (2011). Exhumation and erosion rates in southern Africa from apatite fission track and (U-Th/He analysis: State of research, on-going work and future perspective. In AGU Fall meeting, Abstracts (Vol. 1, 2656p.)

Wildman, M., Brown, R., Watkins, R., Carter, A., Gleadow, A. and Summerfield, M., 2015. Post break-up tectonic inversion across the southwestern Cape of South Africa: new insights from apatite and zircon fission track thermochronometry. Tectonophysics, 654, 30-55.

Williams, A.F., 1930. Diamond-bearing alluvial gravels of the Union of South Africa. 3rd Empire Mining and Metallurgical Congress, South Africa, 21-189.

Williams, A.F., 1932. The Genesis of the Diamond. Ernest Benn Ltd, London, Vol 2, 354-636.

Wilson, M.G.C., Henry, G. and Marshall, T.R., 2005. Alluvial Diamonds of the Northwest Province. Report of the Council for Geoscience of South Africa, 
EARLY PERMIAN DIAMOND-BEARING PROXIMAL ESKERS IN THE LICHTENBURG/VENTERSDORP AREA OF THE NORTH WEST PROVINCE, SOUTH AFRICA

2005-0096, 50pp.

Wilson, M.G.C., Henry, G. and Marshall, T.R., 2006. The diamond industry and the gravels of the North West Province. South African Journal of Geology, $109,301-314$

Wilson, M.G.C., McKenna, N. and Lynn, M.D., 2007. The Occurrences of Diamonds in South Africa. Council for Geoscience of South Africa, Mineral Resources Series, $105 \mathrm{pp}$
Wilkins, C.B., Eriksson, P.G. and van Schalkwyk, A., 1987. Two generations of karst-fill sedimentary rocks within Chuniespoort Group dolomites south of Pretoria. South African Journal Geology, 90(2), 155-167.

Editorial handling: L.D. Ashwal 